\title{
Ceramic Production Technology among the Asurini of Xingu: Technical choices, transformations and enchantment
}

\section{Fabíola Andréa Silva ${ }^{1}$}

${ }^{\top}$ Museu de Arqueologia e Etnologia, Universidade de São Paulo, SP, Brasil

\begin{abstract}
Several studies in the anthropology of techniques have emphasized that beyond their material and pragmatic aspects, technologies are social constructs that produce meanings. Moreover, technical processes mediate relations between persons (human and nonhuman) and things, as a mode of transformative and symbolic action for the (re)creation of the world. In this article my intention is to present an ethnographic description of the ceramic production technology of the Asurini do Xingu to show the intertwining of the technical choices with the principles and social, aesthetic and cosmological perceptions of this people about the objects, and materials, and their transformations.
\end{abstract}

Key words: technology; ceramics; technical choices; transformations; enchantment; Asurini do Xingu. 


\section{Tecnologia de Produção Cerâmica entre os Asurini do Xingu: \\ Escolhas Técnicas, Transformações \\ e Encantamento}

\section{Resumo}

Vários trabalhos de antropologia das técnicas e da tecnologia têm enfatizado que para além dos seus aspectos materiais e pragmáticos, as tecnologias são constructos sociais que produzem significados, ou ainda, que os processos técnicos mediam relações entre pessoas (humanas e não-humanas), materiais e substâncias (tangíveis e intangíveis), como um modo de ação transformativa e simbólica para a (re)criação do mundo. Neste texto minha intenção é trazer uma descrição etnográfica da tecnologia de produção cerâmica dos Asurini do Xingu a fim de mostrar o entrelaçamento das escolhas técnicas com os princípios e percepções sociais, estéticas e cosmológicas, próprios deste povo, sobre os objetos e os materiais e suas transformações.

Palavras-chave: tecnologia; cerâmica; escolhas técnicas; transformações; encantamento; Asurini do Xingu. 


\title{
Ceramic Production Technology among the Asurini of Xingu: Technical choices, transformations and enchantment
}

\author{
Fabíola Andréa Silva
}

\section{Introduction}

The Asurini have always been recognized for their refined aesthetic sensibility and ability to make beautiful things with a wide range of raw materials, including industrialized materials. The transmission of knowledge and cultural reproduction take place for the Asurini through the elaboration, use, storage and disposal of their objects. These actions allow them to reaffirm their worldview, think about themselves and re-elaborate their notions of identity and alterity (Müller 1990, 2002; Ribeiro 1982; Silva 2000, 2013).

Passing through their villages it is possible to observe a profusion of objects spread throughout the spaces for domestic and ritual activities and in the areas used for disposal. They are various objects produced with raw materials and techniques specific to the Asurini as well as those produced from the incorporation of non-Asurini raw materials and techniques. These objects are joined by those that are industrialized (Silva 2013). Among their productions, the ceramic vessels - which they call pot - stand out for their beauty and their social and symbolic importance. They have various formal shapes that correspond to their functions (for ex. cooking, serving, consuming, transporting and storage) - as indicated in the chart below - and some are carefully painted with a broad variety of combinations of motifs related to Asurini cosmology (Müller 1990, 1992; Silva 2000).

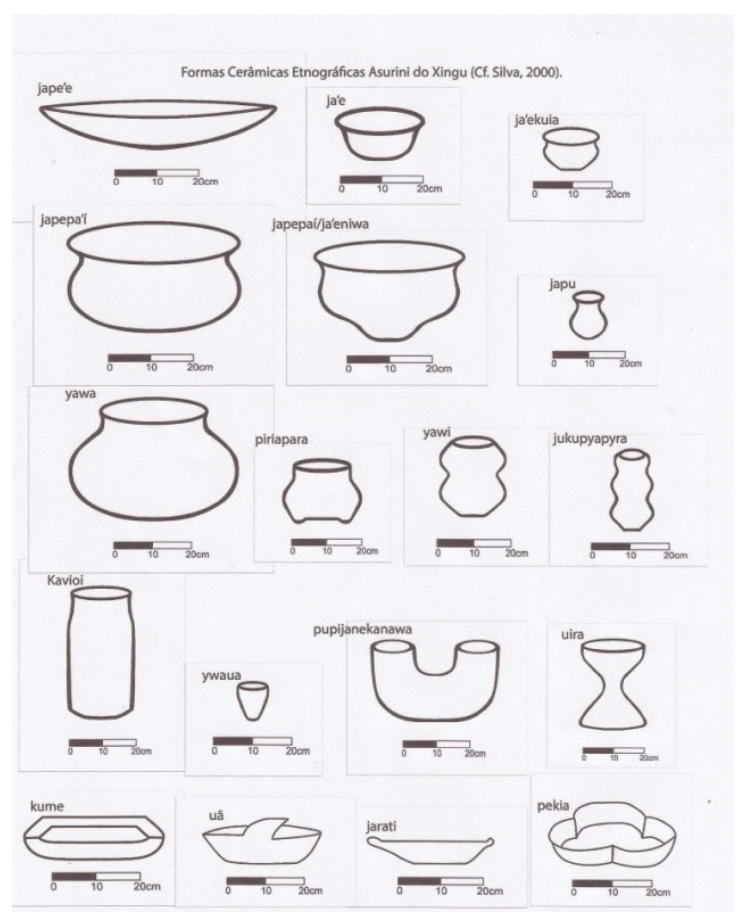


Each type of vessel is developed through a relationship between form, surface treatment and use. The ja'é vessel, for example, used to serve food, has a quite pronounced lip, and this attribute is always painted with the ja'ekynga (head of the ja'e) motif, to highlight it from the rest of the vessel that is usually painted with an infinity of other motifs. In this way, the a japepa'i vessel, which is used for cooking, has a less pronounced lip, a more rounded formal shape and its outside walls are not painted (Müller 1990; Silva 2008) (Figure 1 and 1a).

Fig. 1.ja'é vessel (for serving)

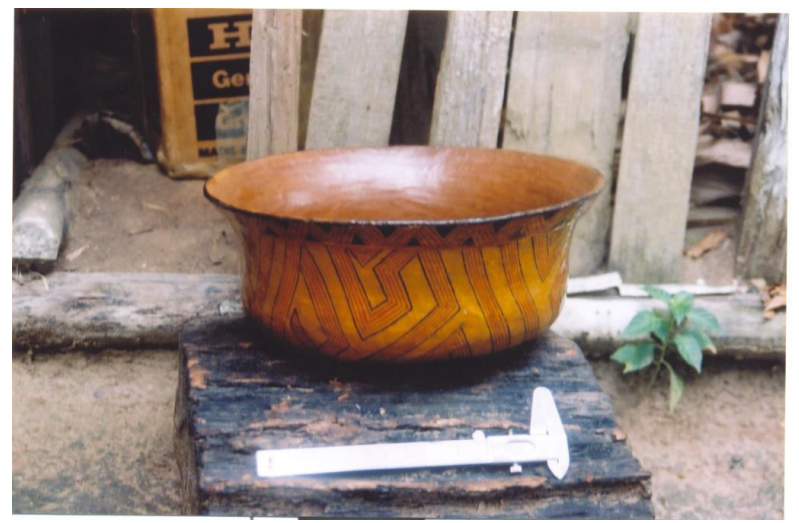

Fig. 1a.japepa’i vessel (for cooking)

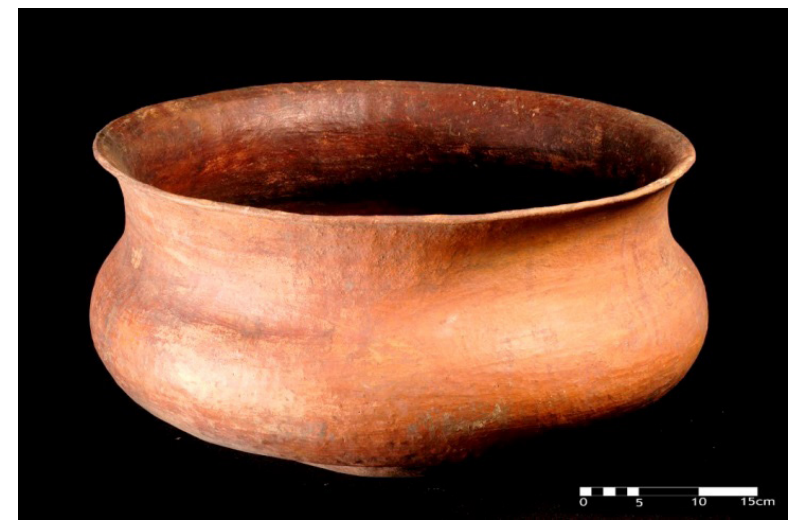

For the Asurini, all of the technical processes undertaken along the operating chain for the production of their objects have an aesthetic dimension; that is, they are also "aesthetic processes" (Barcelos Neto 2005/2006:369). As I will show in this article, in their ceramic production technology it is necessary to "make [the vessels] beautiful", "smooth them beautifully", "burn them beautifully" and "paint them beautifully". Thus, functionality and beauty are inseparable and indistinguishable aspects in the Asurini concept of these objects. It can be said that for the Asurini, useful things must be beautiful as beautiful things must be useful (Müller 199o; Silva 2000, 2009a, 2013).

\section{Some social aspects of ceramic production technology}

The production of the ceramic vessels among the Asurini is an eminently female task, and the teaching and learning of the techniques is based on encouraging observation, and on the practical and repetitive exercise of making these objects. The teaching is highly regulated and involves verbalization and demonstration by the experienced potters of the technical procedures and of the results to be attained in each step of the production sequence, and the performance of the apprentices in reproducing each one of these procedures, along the entire operational sequence (Silva 2009b, 2010). Perception and action are at the heart of the acquisition of this knowledge, implying a corporal conditioning, the embodiment of the technical abilities (Ingold 200o); that is, a girl's body is transformed into the body of a woman potter. Learning to make "pots" fundamentally takes place within the domestic group, based on the transmission of knowledge and expertise from the older women (for ex. mothers, aunts, grandmothers, sisters) to the younger ones (Figure 2). This is a long process that takes place throughout a girl's childhood and puberty, and at times, continues into adulthood, when she is already married and has children. If a young potter leaves the maternal home after her wedding, ${ }^{1}$ she will conclude her learning with the women of her husband's domestic group (for ex. her mother-in-law,

1 Although uxorilocality is the residence rule after marriage, young couples do not always continue to reside in the house of the woman. 
sister-in-law, and her husband's grandmother and aunt) and, over time, participate in the teaching of her younger sisters-in-law. This network of social relations through which this technical knowledge is transmitted also delineates the objectives of this ceramic production.

Fig. 2. Kira'í learning to make a pot with her mother Muruka'í

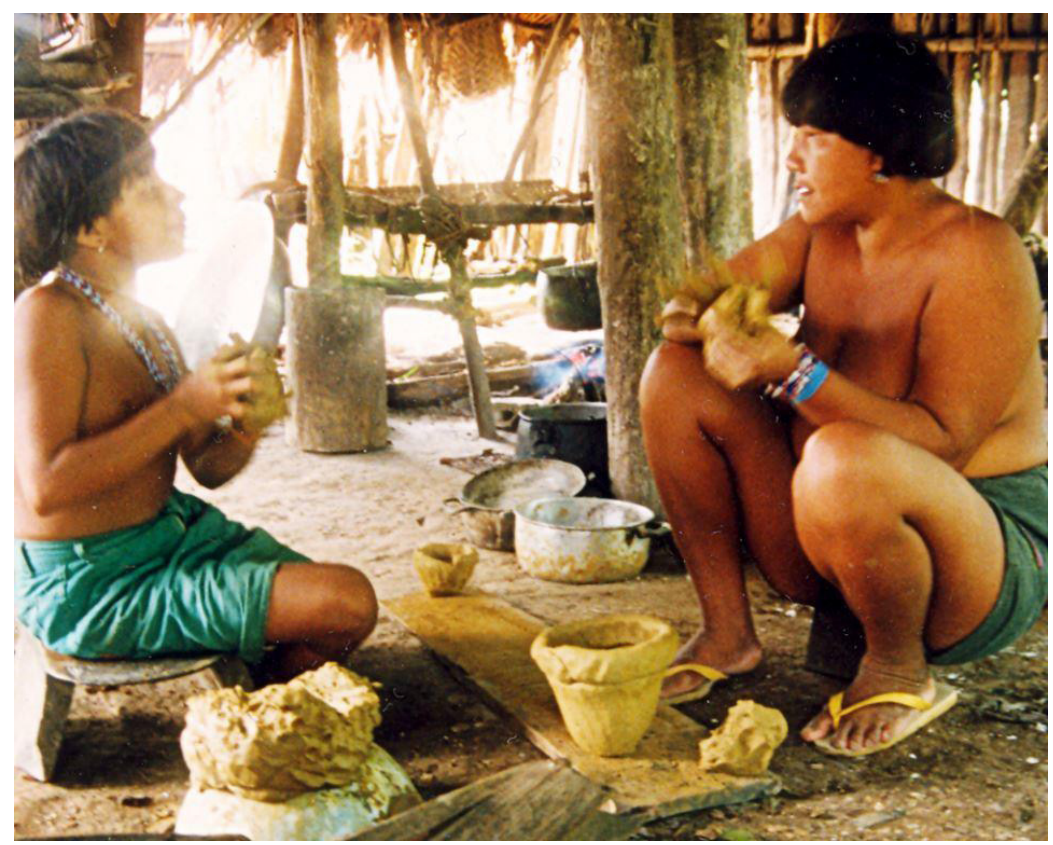

The learning begins around 5 or 6 years of age, when girls begin to more systematically observe the potterymaking activities of the women in their domestic groups and to imitate their actions. A girl begins to acquire her abilities, by accompotying the collection of clay, painting miniature vessels - made by the older women for didactic purposes - and also by making their own miniatures based on which, over time, they learn to dominate the rigorous Asurini cannons of proportionality in the morphology of the vessels. As they acquire knowledge of the pottery production techniques, they also become familiar with the nomenclature and functionality of the vessels, and learn to develop their own work tools (for ex. smoothing tools made from gourds, vegetable and feather brushes and wood spatulas) and to collect and process the raw material.

The learning of pottery technology takes place in parallel with learning about activities in the gardens, gathering, food preparation, rituals and other techniques used to produce other objects that are female prerogatives (for ex. hammocks, baby slings, and cotton body ornaments). Complete command in ceramic production technology is normally attained at an adult age - close to 30 or more - and provides a woman social recognition. It is important to say that among the Asurini, the people most skilled in the production of objects are also those who have the most knowledge of the oral tradition and ritual performances, of social etiquette and subsistence strategies and are often shamans, and social or political leaders. Knowledge in these different aspects of life propitiate to them the status of adults, and certifies them as awaeté, truthful or genuine Asurini person. 


\section{The production process of ceramic vessels}

The production process of ceramic vessels is conducted through an chaîne opératoire whose sequence of actions is shared and reproduced by all the women. To make ceramics, or, as the Asurini say, "mapapira uapá" (make pot) is an activity that they highly appreciate, whose technical procedures are realized with great interest and dedication and through a dynamic that is established among the precepts of the tradition of production ${ }^{2}$ and their individual creative experience. All of this technical care results in ikatu vessels, that is, those that they consider to be beautiful, and that have functional, aesthetic, social and symbolic efficiency.

The sequence of actions that takes place along the operational sequence involves technical choices by the women. These choices, in turn, define the way that the Asurini make pots, their technical style. This technical style is understood as the processual dimension of the style and refers to the way that people realize their technical activities, that is, it relates to the choices that they make about the materials, techniques, tools and the way - sequential and or concomitant - that the technical actions should be conducted along the chaîne opératoire (Carr 1995a, 1995b; Hegmon 1992, 1998). In recent years, various researchers have sought to understand the relationship between technical style, identity and social boundaries, demonstrating that the difference or similarity between technical styles of different populations can be related to their social, linguistic and cultural similarities or differences, on local or regional scales (p.ex. Chilton 1998; Gosselain 200o; MacEachern 1998; Hegmon 1998; Haour et. al. 2010; Wiessner 1983). It has also been revealed that the visual characteristics of the objects (for ex. morphology, surface treatment, weave), and the technical knowledge needed to produce them, are both involved in the constitution of their social and symbolic meanings (for ex. Barcelos Neto 2008; Gell 1992; Gosselain 1999; Hugh-Jones 2009; Munn 1977; Silva 2011; van Velthem 2003; Walker 2009).

Therefore, the concepts of technical choices and technical styles are based on the premise that people have a range of opportunities and options available to them to learn their technical activities (Gosselain 1992; Lemonnier 1992, 1993). This implies understanding technologies to be a result of a complex inter-relationship between materials, energy, knowledge and the social and symbolic universe of human collectives (Pfaffenberger 1992; van der Leeuw 1993). Thus, by describing the technical choices and the technical style of the Asurini potters, I intend to demonstrate that their ceramic technology is not determined by the physical and chemical coercions or potential of the raw materials (for ex. clays, pigments, resins), or by the functional effectiveness intended for the vessels, but that it is the result of how the women apprehend the materials, the technical procedures and the ceramic vessels. My intention is to reflect on this Asurini ceramic production technology in terms of their interlacing with the social, aesthetic and cosmological principles and perceptions of this people about the world of objects and materials and their transformations.

\section{The operational sequences and technical choices}

In general, the operational sequence for pottery production follows some basic operations that are similar to those observed in other contexts of potters. It includes 1) selection and securing of raw materials; 2) preparation of the raw material; 3) manufacturing the vessel; 4) drying; 5) firing; 6) and finishing the surface ${ }^{3}$.

On the following pages I will describe this sequence of actions and techniques and to do so I will use as many photographic images as possible, which I hope can serve as a way to make this experience understood "to someone who was never there" (Samain 2006: 57). During my research about the Asurini ceramic technology I produced an archive of approximately 4,500 photographs (analogical and digital) which provide an account of

\footnotetext{
2 I understand tradition of production as a "shared dispositions guiding choices in the chaîne opératoire of production" (Dietler and Herbich, 1998:255).

3 The definition of this operational sequence resulted from ethnographic observation and interlocution with the Asurini potters, given that operational sequence corresponds to the way that they themselves order the actions needed to transform the clay into a ceramic pot. The description of the actions in the production sequence was realized through the perspectives of Myra Asurini, Parakakyja Asurini, Apirakamy Asurini and Wewe'i Asurini. They also defined the spelling of the lexicon of the ceramic production technology (Silva 2000).
} 
this experience that is lived and shared among and with this indigenous people. The use of the photography was essential so that I could visually register the technical actions of the women and the various aspects related to the production contexts. In this way, I could analyze and re-analyze the technical processes beyond my fieldwork experience ${ }^{4}$. Therefore, the photographs serve as a technical instrument, a narrative resource and a research object - data. As various authors indicate, images are translations of ethnographic experience based on a certain view, and can acquire different analytical meanings (Banks and Morphy 1997; Edwards 2001; Ribeiro 2005). I understand that the images in this text are an essential part of my explanation, and at the same time, allow readers to accompoty my narrative, or even to question it through their own look at the images.

\section{Selection and obtention of raw materials}

During my research (1996-2018), the Asurini women used three sources of clay (jae'uma kwara) to make their vessels. All were located close to the village, gardens and on the margins of the Xingu River - some $2 \mathrm{~km}$ to $8 \mathrm{~km}$ from the Kwatinemu village - and easily reachable by foot or boat. One of the sources of clay has been used since the beginning of the occupation of the Kwatinemu village in the early $1980 \mathrm{os}$, because it has "good clay", according to the Asurini. The other sources were abandoned some time ago, because "the clay is no longer useful" - in fact clay deposits can be depleted as they are used. It should be said that in their discourse the Asurini women do not indicate that a source of clay is chosen as a function of its proximity to the village, but in practice, the sources they use are nearly always close to their villages.

With each installation of a new village, one priority is to locate "a good clay" to make the ceramic vessels. Normally, the sources of clay are found during the incursions of men and women through the forest or the recently-opened planting fields, considering that they are always attentive to possible signs of this raw material. Those that I observed being explored are found close to the surface of the earth and were revealed by erosion or various bioturbations (for ex. close to a fallen tree with exposed roots, at an armadillo den, in a grotto or storm gulley).

The "good clay" for making a pot has the following characteristics, according to the Asurini: "it is not sticky and stays firm for making the pot"; "it is smooth and has little dirt"; "it has the color of a pot"; "it does not crack when it is dried or fired". Thus, each time that a new source of clay is discovered, they "experiment with the clay" to see if it has these qualities. They usually rub the clay between their fingers and chew it to perceive its texture and the quantity of sand and water (Figure 3). In addition, they take samples of clay to the village and make small vessels to check its performance during drying and firing. Therefore, the choice of a source of clay depends on the performance of this raw-material, according to the prerogatives of the Asurini women.

4 Over my twenty-three years of research with the Asurini do Xingu I have produced an archive of more than 15,00o photographs, which is the object of a project of curatorship and reflection about the uses of photography in anthropological and archeological research (Silva and Pellegrini 2019). 
Fig. 3. Ipikiri collecting clay

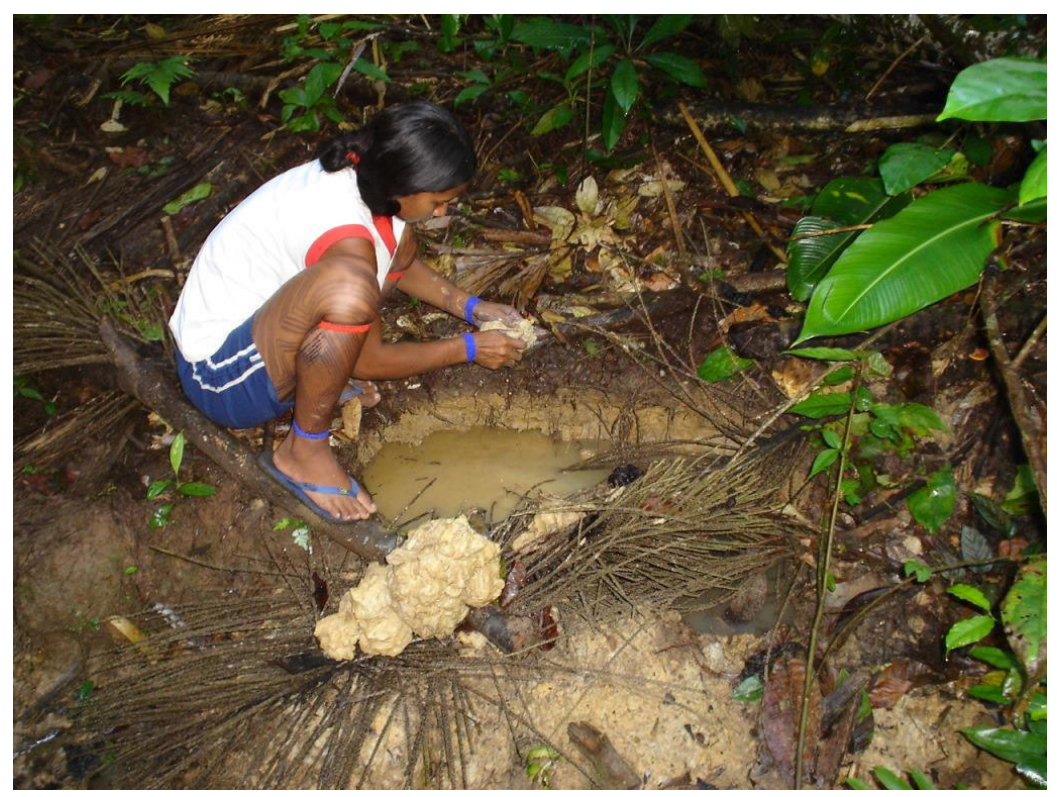

From a mineralogical point of view it can be said that in the choice of clay the Asurini consider the plasticity, granulometry and the amount it contracts during drying and firing (Munita et al. 2005; Silva 2000; Silva et. al. 2004). All of the clays that present the qualities needed to be used in the preparation of the ceramic vessels are defined indistinctly as jae'uma eté (true clay). Clays not suitable for this use are known as jae'uwyrĩg $a$ (yellow clay), jae'upyrĩga (red clay), itauatiga (white clay), jae’umuvi (bluish clay; very plastic), ityjuká (white clay) and jae’ujuva (black, shiny clay).

The archaeometric analyses of the clays from different sources used by the Asurini reveal that they involve raw materials that are different in mineralogic terms, but that have a high and average concentration of sand and grains of quartz - characteristics that result from the process of sedimentary deposition of the clays ${ }^{5}$. One of the sources (source A) has clays belonging to the kaolinite and halloysite group and the other (source B) to the smectite and illite group (Silva 2000; Munita et. al. 2005). In the production of ceramic objects, these two groups of clays have general performance standards that are a bit different: 1) the clays of the kaolinite and halloysite groups (source A) have good plasticity, low contraction during drying and good performance when firing; 2) the clays of the smectite and illite group (source B) have materials that absorb and retain a larger quantity of water, a factor responsible for the high plasticity and increased probability of contraction during drying, and breaking during the firing (Rice 1987). What was interesting about this experiment was to find that in their practice the potters recognize the differences in the clays. They say that the clay from source B, although it is "good to work with" - i.e. malleable - was more likely to break during drying and firing the vessels. This source wound up being abandoned at the end of the 199os, while source A continued to be explored in the following decades.

The selection of the clays and of the tempers is an essential procedure and always conducted with great care by ceramist populations, and it varies considerably, given that it is related to various economic, technical, social, political and symbolic factors. In the case of the Asurini, the selection of a certain clay is directly related

\footnotetext{
5 Thirty-five clay samples were analyzed with the following techniques: 1) Infra-Red Absorption Technique, by Prof $\geqq$ Dra Maria Tereza Nóbrega, Geography Department, Universidade Estadual de Maringá; 2) Neutron Activation Analysis, by Prof. Dr. Casemiro Munita, of the Instituto de Pesquisas Nucleares (IPEN), São Paulo).
} 
to the fact that women do not intentionally employ any type of antiplastic (temper) ${ }^{6}$ in the ceramic paste. It is inconceivable to them to add any substances to the clay, because this would mean "dirtying the clay" which in their perception must be clean from the impurities that it contains (for ex. organic material and stones). Therefore, the clays that they use usually have a high and or average concentration of sand and grains of quartz, given that these materials act as a natural hardeners, regulating the characteristics of plasticity and extensibility of the clay. What is important for the Asurini in the process of selection of sources are the performances of the clays, more specifically, how they behave during the operational sequence of production, that is, "the clay is good for making pots". For the Asurini, only after experimenting with the clay can it be said that it is jaéuma, that is, "that which will become ja'e", a pot.

In his reflections on materials and materiality, Ingold (2011a, 2011b) proposed that the "active properties of the materials" should not be identified as fixed attributes, but as processual and relational stories to the degree to which they are neither objectively determined nor subjectively imagined but experienced in the very practice of working with the materials. According to Ingold, the material is in movement, in flow, in variation and the artisans follow the material, they are itinerants, guided by the "intuition in action". The Asurini potters appear to collaborate this concept, because they exalt the qualities of the clays and define the sources to be explored through their sensorial experience with these raw materials. That is, the properties of the clays reveal themselves through touch (sticky/not sticky), sight (color of the pot) and palate (smooth/dirty). They recognize the active properties of the clays based on that which the clays do, and not from what they are in an intrinsic way. For this reason, different clays - from a mineralogical perspective - can be jaéuma. It can be said that in Asurini thinking, the clay is a living thing that has subjectivity and intentionality, given that this becomes clear in various steps of the operational sequence as I will show further on. So much is it alive, that it needs to be killed (aajuka), crushed, (de)subjectivized to be able to be transformed into a ceramic pot.

In terms of the form of exploration of the sources of clay, this is done indistinctly by all the women who share this task in three different steps: jae'uma katy'a = looking for the clay; jae'uma aak = removing the clay; jae'uma aerut = transporting the clay. The clay is removed with the assistance of a digging stick and during the operation they eliminate the excess stones and organic material that may be present. When the men find a source of clay during their incursions through the forest they eventually bring a small sample for the women to determine if "the clay is good". When the source is close to the village the women test the quality of the clay in situ. The baskets used to transport the clay from the source to the village are of the "poteiroforme" (pyrywytiga) and "jamaxim" (manakutiga) types and the quantity varies according to the pretensions of each woman. They rarely stock a large amount of clay in the village, given that the reutilization of clay after it dries requires a relatively laborious process, according to the potters.

Pregnant or menstruating women should not "remove the clay", because it "becomes ruined" and the vessels can crack or break during the drying or firing. Nevertheless, they may accompoty the other women to the place of the clay, observe its extraction and later, help to transport it to the village; but they should not touch the clay.

As was demonstrated by various authors, for the different indigenous peoples of the Amazon, the meaning of certain substances, fluids and altered states of the body are related to their conceptions of corporality (for ex. Seeger et al. 1987). In relation to menstrual blood, this can be associated to notions of impurity, danger or interdiction and there are various mythical stories that link the origin of menstrual bleeding to incestual sexual practices. Menstruation is also related to other transformational processes of the body of women such as conception, gestation and post-partum bleeding. Normally, pregnant or bleeding women interrupt their execution of some daily tasks, observe sexual abstinence and avoid consuming certain foods (Belaunde 2006).

6 In some bibliographies the word temper is used to define a hardening agent that was intentionally added to a ceramic paste, in contrast to a natural hardener found in situ in the clay deposits (Rice 1987). 
In the Asurini case, the origin of menstruation is related to the myth of Jaytita that refers to the theme of incest and the dangerous consequences of this act for humanity. In the myth, Jaytitá wants to have sexual relations with his sister Arimajá who rejects him and through a ruse paints Jaytitâ's face with jenipapo. Ashamed, he decides to abandon the world of humans and rise to the sky, accompotied by his relatives. Using a cord made of arrows they rise, and as Jaytitá goes higher he throws arrows back to earth, which dangerously hit the ground and enter the underground world. Those who remain had to be careful not to pull out the arrows, because if they did the world would be flooded by subterranean waters. When he reached the sky Jaytitá became Jay (moon), and warned that his face should not be seen, because this could cause evil. However, on the full moon women looked at Jay's face, and for this reason began to menstruate (Müller 1990:334-335).

For the Asurini, the menstrual blood is perceived as a substance that can be harmful for those who contact it, particularly men. Moreover, menstruation and pregnancy are physiological processes that require that women care for their bodies. In relation to conception and pregnancy, the woman's blood is seen as a substance complementary to semen in the formation of the fetus. According to the Asurini, various sexual relations are needed and various transfers of semen for a good formation of the fetus. The woman's blood is the substance that nurtures the fetus, while the semen is the substance that forms the fetus. Thus, menstruating and pregnant women, in addition to not removing the clay also, eventually, avoid working with the clay, because they say the ceramic vessels are often damaged. In addition, they do not eat "stronger" meat (for ex. tapir, paca), they do not have sexual relations with their husbands and abstain from planting corn.

Ceramic technology is a theme that is very present in the Amerindian cosmology and is normally associated to the mythical stories about the genesis of the world and the creative acts of the demiurges. In addition, the clay, because its origin is related to the transformational processes and creative actions of these beings, has its manipulation involved in care, precepts and prohibitions (p.ex. Lévi-Strauss 1986). Like other materials, it can also manifest the moods, behaviors, and therapeutic and or pathogenic powers of its "owners" and present certain properties that define its efficiency, potency and agency (p.ex. Barcelos Neto 2009; Bealunde 2017; Fausto 2008; Silva 2011; van Velthem 2009).

In Asurini cosmology, bees (jautipitá) are the "owners" of the clay, and they fly over the clay deposits and the clay sticks to their feet. According to the Asurini shamans clay was created by Maira - the demiurge creator of humans, and of all things and techniques - but it was the beetle (mamygá) who showed this material to the bava (ancestors), pushing it from underground to the surface.

Handling clay is the prerogative of the Asurini women, while the men also come into contact with it in a few situations of daily life and ritual life. In different Amazonian populations a relationship between gender and certain objects, substances or raw materials can be noticed (p.ex. Silva 2011; Londoño 2012). For the Asurini, the clay is eminently associated to the feminine gender; "it's a woman's thing" according to the Asurini men.

\section{Preparation of raw-material}

The process of preparation of the raw material is relatively simple and the first operation is defined with by expression ja'e uma aajuka, which can be translated as "to crush or kill the clay". It involves kneading the clay while it is still moist, hitting it with a stick and later with their fingers and removing its impurities, such as, leaves, roots and stones (ita aak = remove stones). They continue to make a pile of the processed clay until they reach the amount needed to make a vessel (Figure 4). When they process a clay that is already dried because of its time in storage, the work takes longer. They grind the stiff clumps of clay and then pass it through a sieve until it becomes like a fine sand. They then rehydrate the clay and begin to knead it with their hands until it reaches the desired extensibility. 
Fig. 4. Tapira preparing the clay for it to become "smooth" without dirt

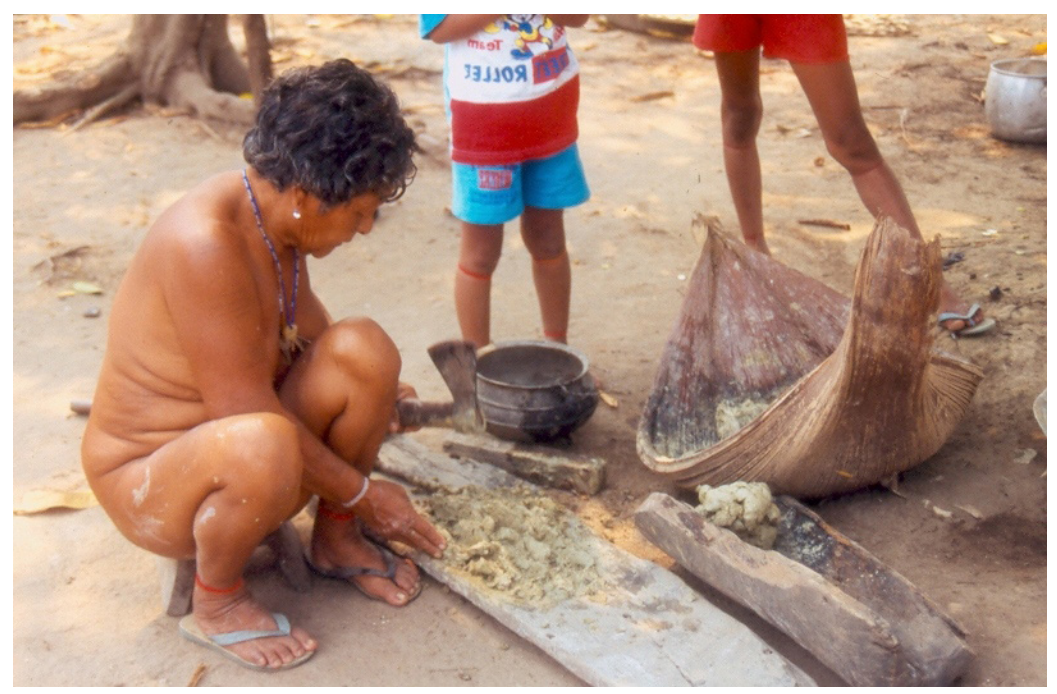

In various contexts of potters the preparation of the clay involves the addition of antiplastic (either mineral or organic), which can have different pragmatic, social and symbolic reasons according to the local context (Arnold 2000; Arthur 2006; Dietler and Herbich 1989; Miller 1985). In the case of the Asurini, as was previously described, there is no intentional addition of antiplastic in the paste considering that the clays are chosen to the degree to which they correspond to the needs of the production process.

\section{Preparation of the vessel}

The technique used for preparing the vessels (japepa'i apa = making a cooking pot) is called coiling, ${ }^{7}$ given that the first operation realized by the ceramist is the production of rolls. They place a portion of clay on a piece of flat wood (ipe) and roll it with their hand to produce a coil (jae'uma amuema = roll the clay) (Figure 5). They then coil one of the coil on the palm of their hand and prepare the base (flat or rounded) of the vessel (apyyk pyyk = grab, seat; amamyn = join). The vessel is always begun from the base that at times may be pinched instead of coiled (Figure 5a).

Fig. 5 and 5a. Tapira making the coil and preparing the base of the vessel
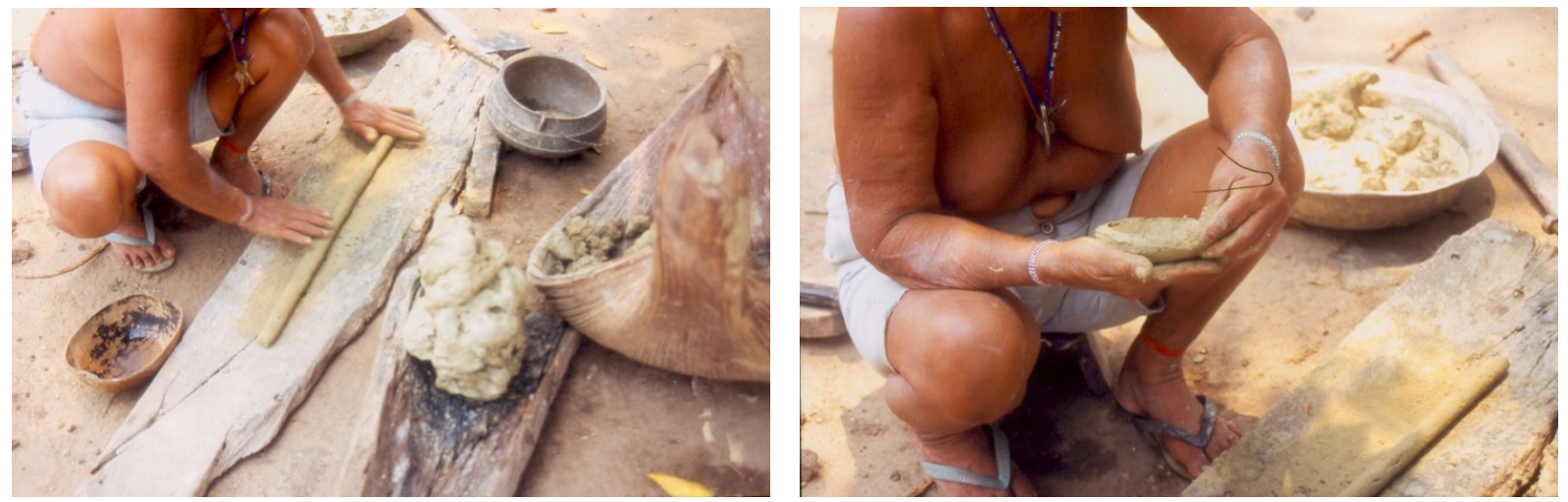

7 According to La Salvia and Brochado (1989:11) the coiling technique is constituted in the "use of coils of clay that are placed on top of each other, to form the intended shape". 
Coils are added to the base to gradually form a cone that initiates the body of the vessel (Figure 6). Later, it is placed on a wooden board called yvyrapyrera and coils are placed on top to complete the body of the vessel (jae'uma amamyn eraka = add the clay that is already made). All types of vessels are prepared from this initial conical shape to which coils are added and expotded until they lead to the desired form. The jape'e, which is the vessel used for toasting flour, is the only one that is not made on the yvyrapyrera, but on a circular base that is dug into the ground, whose size will determine its diameter (Figura 6a). As the women place the coils on top to form the body of the vessel, the women join them with their fingers, to do the initial smoothing of the outside and inside surfaces of the vessel (amamyn apiwuym; apuy piwu = passing the fingers to join, in the sense of smoothing with the fingers).

Fig. 6 and 6a Tapira making a jape'e used for toasting flour
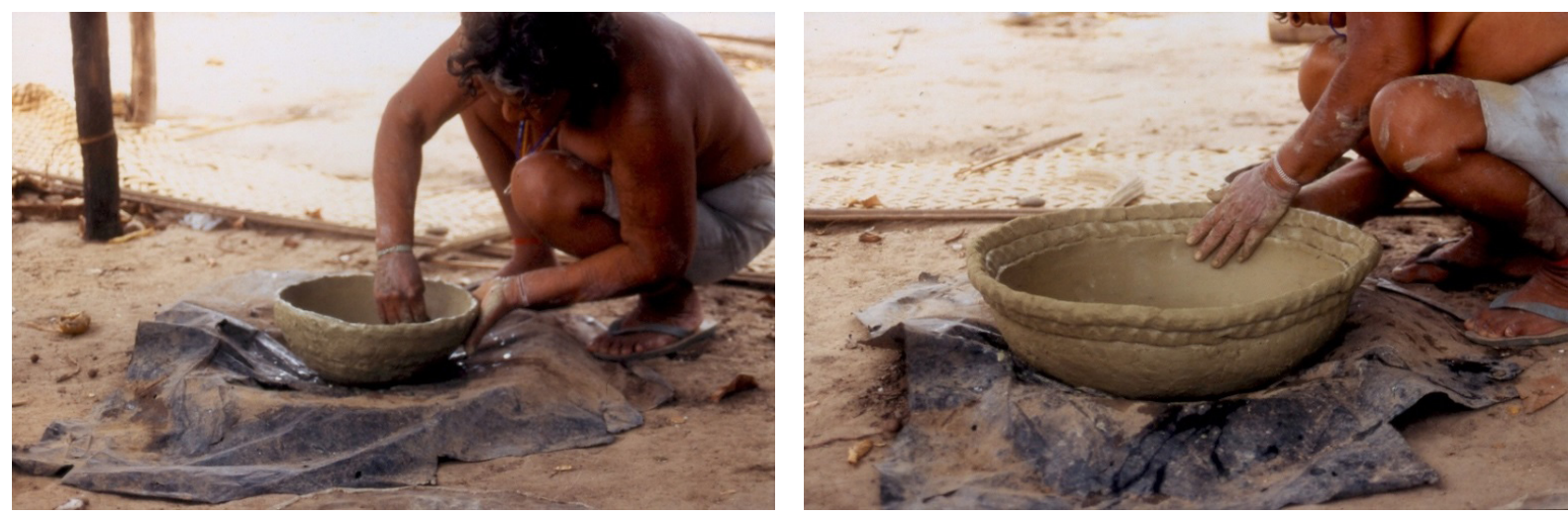

After this, they use a tool made of a gourd to attain a finer smoothing of the surfaces (kuia pywu aka ikatuaka apiree $=$ with the broken gourd beautifully smooth the pot) and produce the formal shape desired for the vessel (Figure 7). They usually place a few layers of coils and then smooth them together, and then add others, and once again smooth them with their fingers and with the gourd, and so on, in succession until completing the body of the vessel (a'amuapepug = widen and expotd the body of the pot). The smoothing tool the women make from a gourd, (kutiape) is essential not only for good smoothing and to define the formal shape of the vessel but also to finish its bottom (ekara akatuaka = fit, leave the bottom beautiful) and smooth its external and internal surfaces. All of these steps are slow and require care, skill and patience.

Fig. 7. Maya carefully smoothing a kumé vessel used to serve food

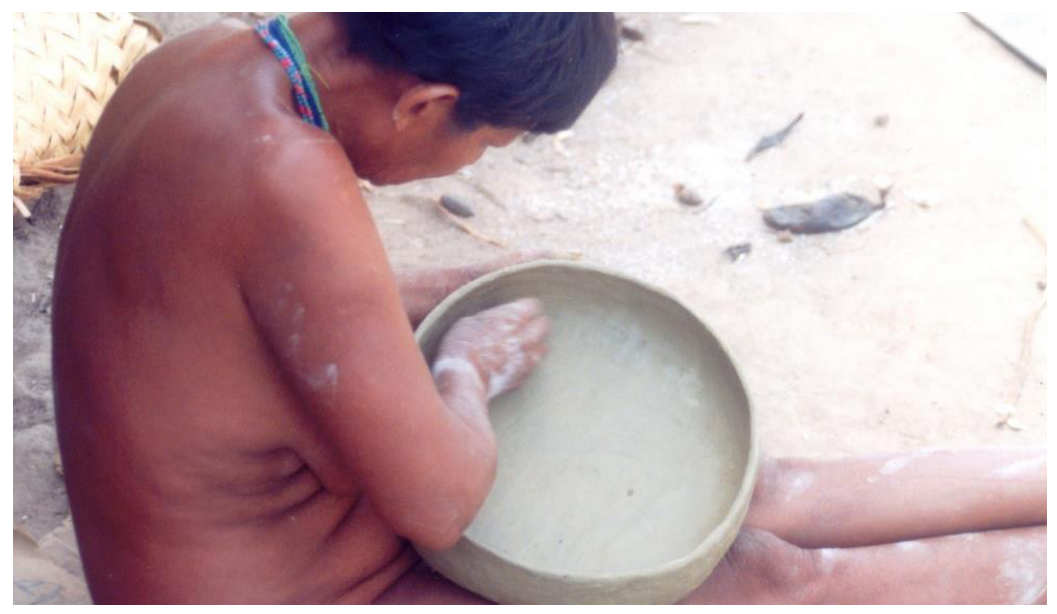


In the mythical stories about the deeds of Maira there is a passage in which the demiurge modeled the body of his son Kyty, smoothing his skin (apiree) so that he becomes beautiful. In the Asurini language, the word for skin is pirera, and when the women smooth a vessel (apiree) they refer to this production step as "smoothing the pot like our skin". The term apiree is only used to describe this step in pottery making, because in other situations the word amukavut is used to mean smoothing in generic terms, in the Asurini language. Therefore, for the Asurini, to smooth a ceramic vessel and carefully finish it relates to the mythic narrative about the perfect and beautiful elaboration of the body of Kyty (Silva 200o).

After the smoothing step is finished and the final shape is given to the vessel, the potters smooth and finish the vessel's surfaces and the lip (Figure 8). To make the vessel lip quite thin they remove small portions of clay with their finger tips (eme akatuak = refine, fit the mouth) and in parallel, smooth the lip with their fingers moistened with saliva (eme rupi apuyp = pass the fingers on the mouth of the vessel) to give it the final finish that, in most cases, leaves it rounded. Saliva is used during the entire process of smoothing the vessel and is considered a substance that helps make the vessel prettier (ikatuakunume ae uendy umuy = embellish, fit with saliva). According to the Asurini "the saliva moistens the clay very well, because the water gets it very moist" or, even, "the saliva leaves the pot with a more beautiful smoothness". It should be mentioned that in the act of passing saliva to smooth the vessel, they also smear their mouths with clay and wind up ingesting some.

Fig. 8. Tapira finishing the edge and lip of the jape'é

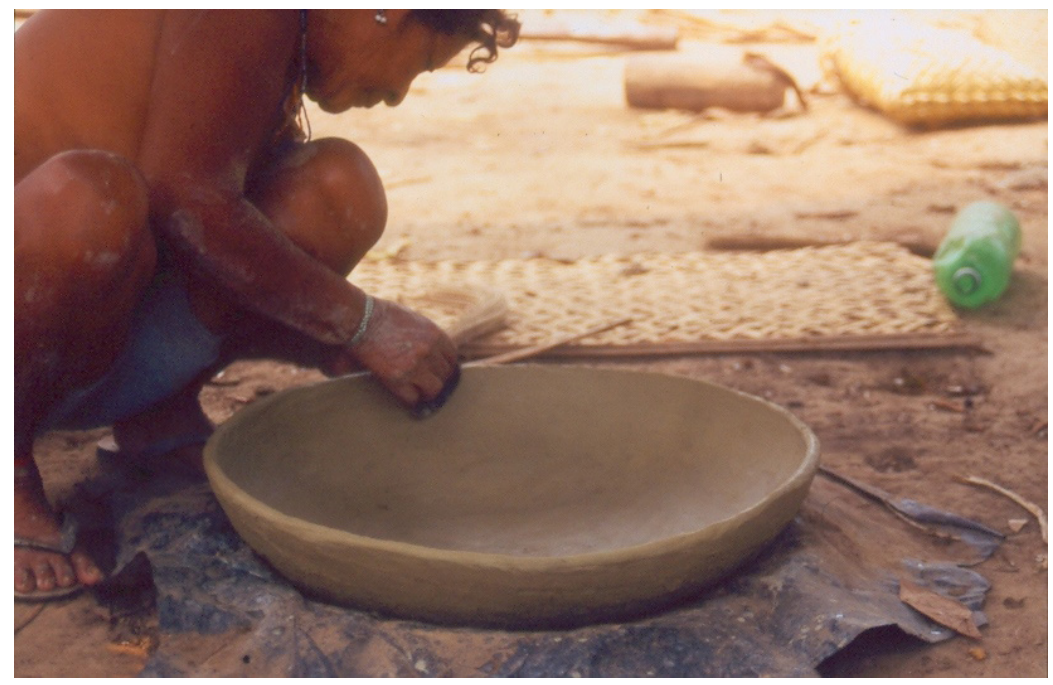

According to Müller (1990:183), among the Asurini, saliva is a feminine substance "that gives origin to the main manifestation of the vital substance", that is, the fermented porridge that is consumed by shamans, supernatural beings and kauirau (initiates) in the rituals. Therefore, the use of saliva to make the ceramic vessels can be understood as more than an aesthetic issue, and is also related to the transformational processes of the ritual performances and with the perception of foods in general as a "vital substance" for the constitution of a person.

Some women abstain from eating and drinking water during the process of manufacturing the vessel, because they say that if they do "the pot does not dry correctly". In addition, they avoid "passing gas", considering that "the clay of the pot cracks when a woman farts". Others stop work to make the meals, or to conduct their domestic tasks and care for the children. Women who have small children are less dedicated to making the ceramic vessels. 
When asked about who had taught these manufacturing techniques to the bava (ancestors), the Asurini mention the myth of Tauvuma, which concerns the origin of the Tauva ritual that relates to the themes of war, the initiation of youth and death, and that has part of the rites conducted by women shaman. Tauwuma is a woman who abandoned the world of the humans and was transformed into Tauva, after her brother killed her "boyfriend" (tapir-man) to whom she served porridge in clay pots, whenever they had sexual relations. In the mythical narrative she, together with the bees, (owners of the clay) and tapiti (female-rabbit) go to look for clay to make the pots. According to the Asurini, it was tapiti who taught Tauvuma to make all the types of pots. Some Asurini also say it was Anumai whose legacy to them was the knowledge of ceramic technology. She was the sister of the primordial shamans and the first uirasimbé, owner of the porridge in the mythic ritual performances. At a certain time when Anumai was cooking the porridge in a japepa $i$, and the shamans were conducting the ritual songs and dances, Tapijawara, a monstrous being, emerged furiously from the underground world. Reacting to the attack of the Tapijawara, Anumai threw her ceramic vessels at his head, and they broke, leaving only sherds spread on the ground (Silva 200o).

\section{Initial drying}

After a vessel is in its definitive form it is placed to dry in the shade (aruyga neiteni utuwiramu = dries in the shade). The drying time is proportional to the size of the vessel and varies according to the season of the year and the weather conditions. In the rainy season, a vessel can take from three to five days to dry and in the dry season one to two days. Normally, the potters dry the vessels inside their homes or in adjacent structures, far from the reach of animals and small children.

Fig. 9. japepa’i vessel drying in the shade in a domestic space

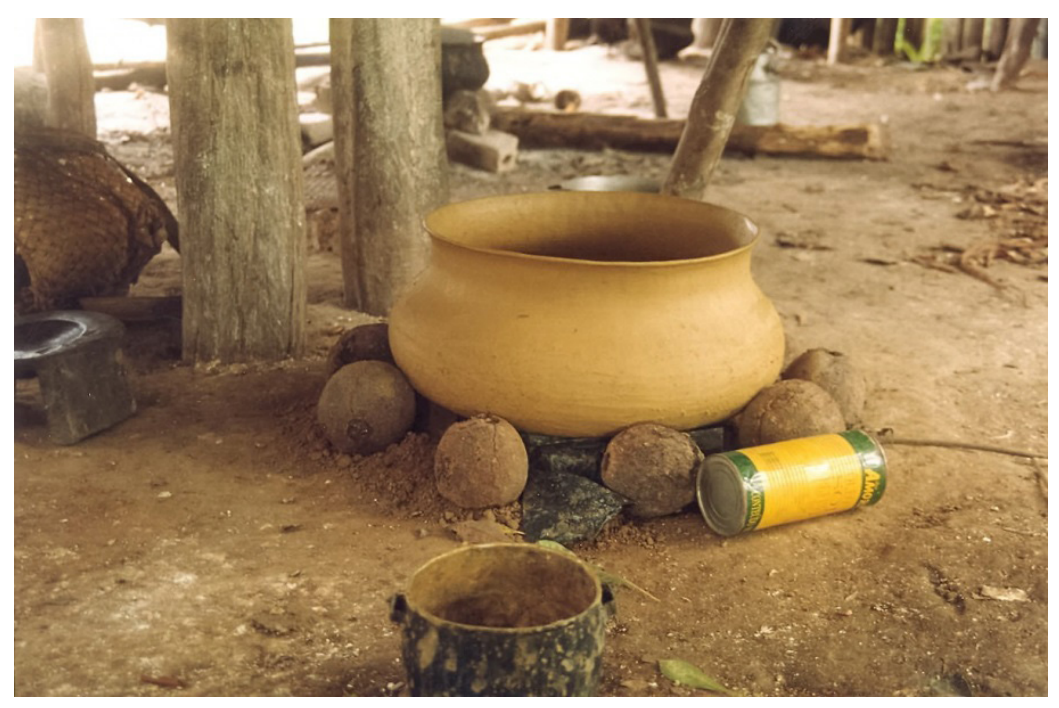

The position for drying the vessels depends on their morphology. The vessels yawa and pupijekanawa are placed with the overture diameter on top and this causes their body to expand during the drying. The japu vessels dry upside down and in this way the neck is set better on the rest of the body of the vessel which, in turn, does not expand as much. The jape'e are dried in the same place as they were made, because it is a large vessel that breaks easily when handled when it is still moist. The types of vessel that have extroverted overture diameter (p.ex. japepaí, ja'e, ja'eniwa) dry with the overture diameter on top or upside down. The large vessels with rounded bases dry with the overture diameter on top and the bases placed on supports (for ex. Clothes, Brazil nut pods or small clay balls) which leaves them balanced and not touching the ground (Figure 9). 
Some potters place a damp cloth on the vessels so that they dry more slowly, to avoid cracking. In addition, while the vessels dry, they improve the smoothing of their outside and inside walls, with a small inajá coconut (inataia'pina) or a smooth stone (itakuy). They rub these tools against the surfaces as the clay hardens (inataia'pina iatajykame apiree $=$ smooth the pot with inajá coconut while it hardens). This process also relates to the myth of Kyty in which there is a passage that describes that while Maira smoothened his skin, he could not move, that is, he had to keep still until it hardened. The Asurini say that his is also how it is when making a clay vessel, "it grows and is smoothed and adjusted until it hardens" (Silva 2000).

The drying causes a retraction in the clay that can may cause small cracks that are repaired with the application of more clay in specific locations. The Asurini usually say that by passing the tiny coconut, and smoothing the vessel while it dries, it is possible to know the right moment to place the vessel on the fire for the final drying.

\section{Final drying or pre-firing}

After drying for a few days, the vessel is placed close to the fire or over coals to become completely blackened by the accumulation of soot (tata pywu amuun = darkened by fire). Generally, they use the fire and coals from the place where they are cooking. This technique helps to complete the drying of the clay and according to the women is used to "leave the pot hot so that it will not break in the large fire" (Figura 10).

Fig. 10. jape'e vessel made by Tapira, drying on the coals

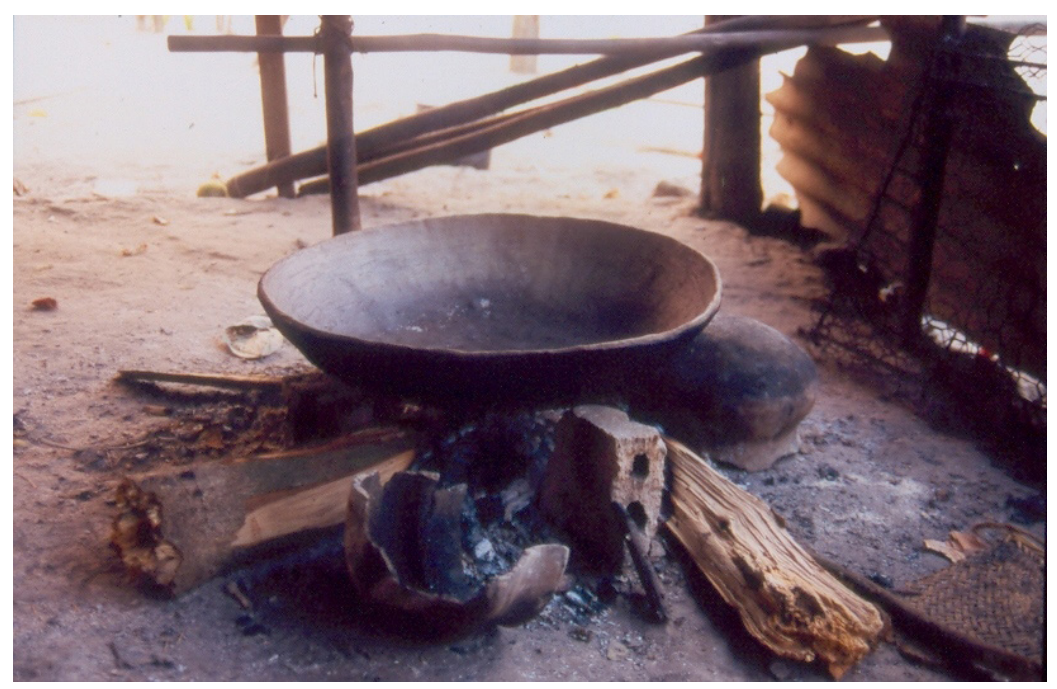

\section{Firing}

After it is totally darkened, and preferably still hot, the vessel will be definitively fired apy pame pywu (fire with a palm spathe). The Asurini prefer to fire the vessels in places farther from their homes, where fewer people pass by and there are fewer objects. Some women say that "the clay does not like noise and the vessel can break if there is a lot of commotion around the fire".

The firing is done outdoors and this technique is known as firing in oxidizing atmosphere, and is common among various populations of potters (Figure 11). It is a relatively simple process from an operational perspective, but complex in terms of the control of the variables and results. In the case of the Asurini, it begins with placing the vessels on a circular structure of bricks or pot sherds, together with a pile of embers. The vessels are then covered with babaçu palm spathes or barks from various kinds of trees, such as: anygirãna (sucupira), jayva (castanha-do-pará), maritauyva (surucucu), jayridi (jarana-mirim), akutitiriwayva (cutite), 
jayrana (jarana-mirim), iwipekatinga (pacovi), ywitiryva (mata-mata), murureyva (pé-de-bucha), jeniparidyva (jenipapo bravo) and iagyva (amarelão); most of which are quite resinous woods that reach high temperatures when burning. The firing varies from $20-50$ minutes and can reach temperatures between $500^{\circ} \mathrm{C}$ to $800^{\circ} \mathrm{C}$, according to the variations in weather, air temperature, number and size of the vessels (Silva 2000).

Fig. 11. japée made by Tapira nearly completely fired

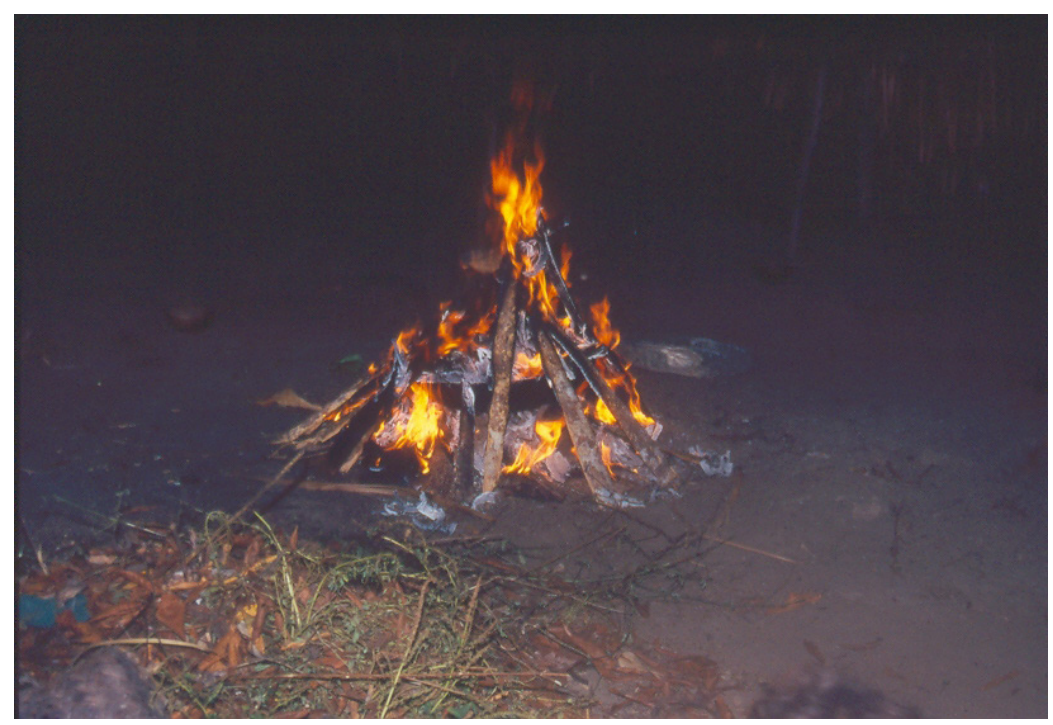

This is the most critical phase of the operational sequence of production for the Asurini women, because all of the previous work will be lost if the firing is not successful; that is, if the vessel breaks, cracks or has many fire-clouds. They refer to this step as apykatu'yva (that which makes it pretty). Normally, they fire the vessels in the late afternoon, which they say avoids unexpected gusts of wind and the temperature is more moderate). A proper firing in the concept of the Asurini is that which results in vessels that have no cracks and whose surface is totally clear, without carbonization marks. This is so important that some women come to fire the vessels again if they have dark stains on the surface. They say that these vessels "did not burn prettily", an expression that is also used in other situations of daily Asurini life, like when burning the gardens or burning a trunk to make a canoe (Figure 12).

In Asurini cosmology the fire is a transformative element that was acquired by humans through the intermediary of Uirá (bird-woman). She took the fire from her brother the king vulture and took it to cook porridge for Ajaré, the only human who survived the flood caused by the monstrous Tapijawara. During the narrative, the king vulture became angry with the theft of his fire, but winds up teaching this technique to Ajaré, and thus, the fire became a property of humans (Müller 1990:341). In their daily life, the fire transforms the wood into a canoe, the brush into a garden, and animals and plants into food. In ceramic technology, it transforms the clay into a vessel, given that this transformation should involve beauty (for ex. an absence of cracks and carbonization marks). In the rituals, the smoke is the means by which the shamans can travel and access other cosmic domains and meet with the supernatural beings that provide the ynga (vital principle) to humans. 
Fig. 12. japepa'i vessel that "did not burn prettily"

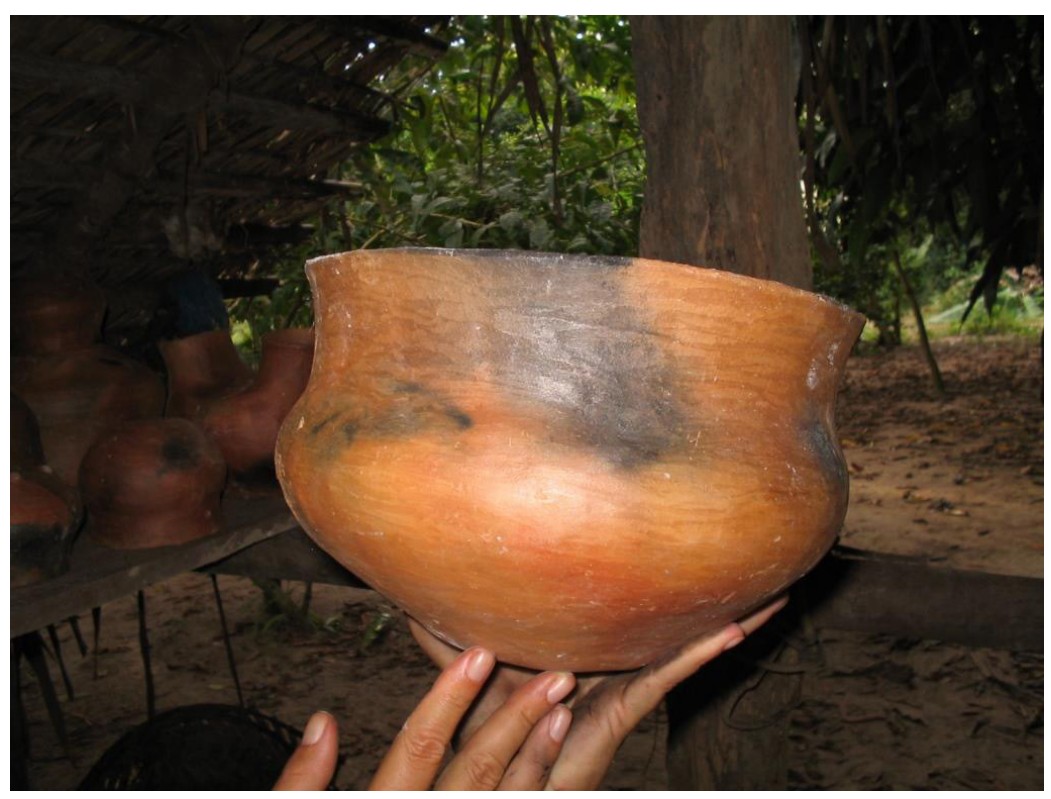

\section{Surface finishing}

The surface finishing is conducted in three steps: painting, the application of resin (jutaika), and the application of titiva (resin from inga sp), depending on the function of the vessel. Vessels that go to the fire are not painted, but receive the application of titiva on their outside and inside surfaces. Vessels that do not go to the fire are painted on the outside, they receive jutaika on the outer surface and titiva is applied on the inner surface.

The painting (japepa'i juak = paint japepa'i) begins with the preparation of the mineral pigments in the colors yellow, red and black (Figure 13 and 13a). The yellow (itaua) and red (itauapirygĩ) pigments are constituted from the iron oxides (goethite and hematite), and the black pigment (itaudi) from manganese. To produce the pigments, the minerals are rubbed directly on a large stone called itauamugyawa - a stone anvil - and mixed with water. These materials are collected by men in their incursions through the forests and are found randomly on the ground or in specific deposits.

Fig. 13 and 13a. preparing the yellow (itaua) and red (tauapirygĩ) pigments
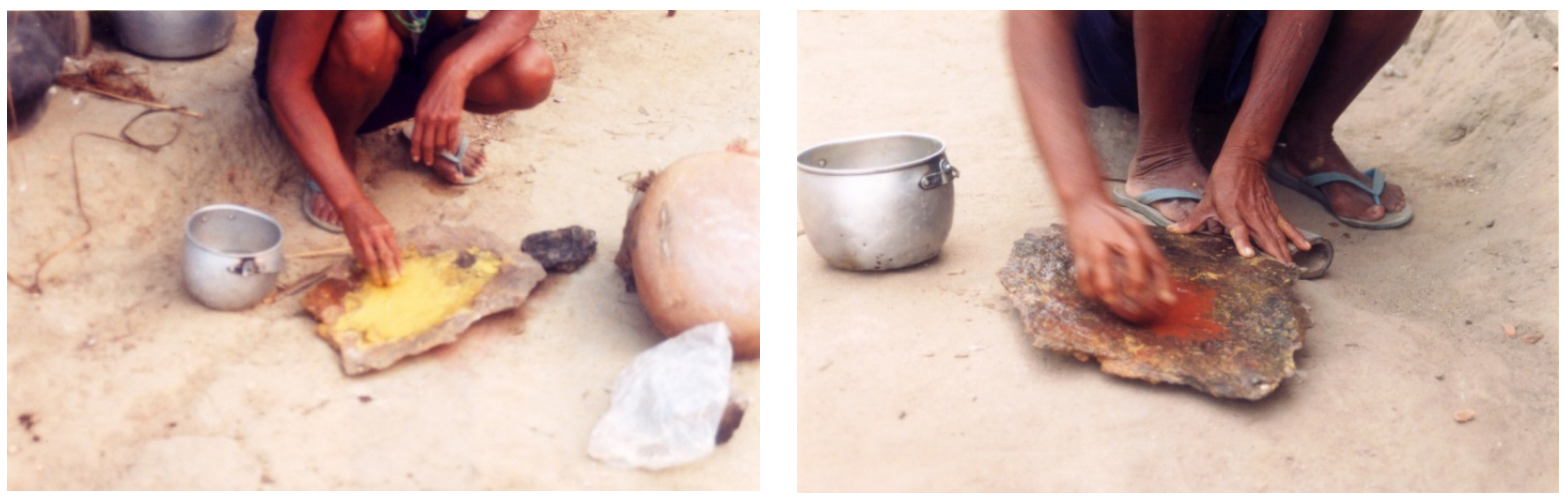
After producing the pigments, the women apply the yellow pigment to the entire surface of the vessel using cotton wadding (amyniju). The yellow pigment is the base for the motifs that are painted with the red and black pigments. Three types of tools are used to apply the motifs: a mutum feather (muturuaja) for the fine lines, and babaçu or inajá stems (pina'wype) and a plant stalk (jupuywa), for the thicker lines (Figure 14 and 14a).

Fig. 14 and 14a. applying the yellow pigment and painting the tayngava
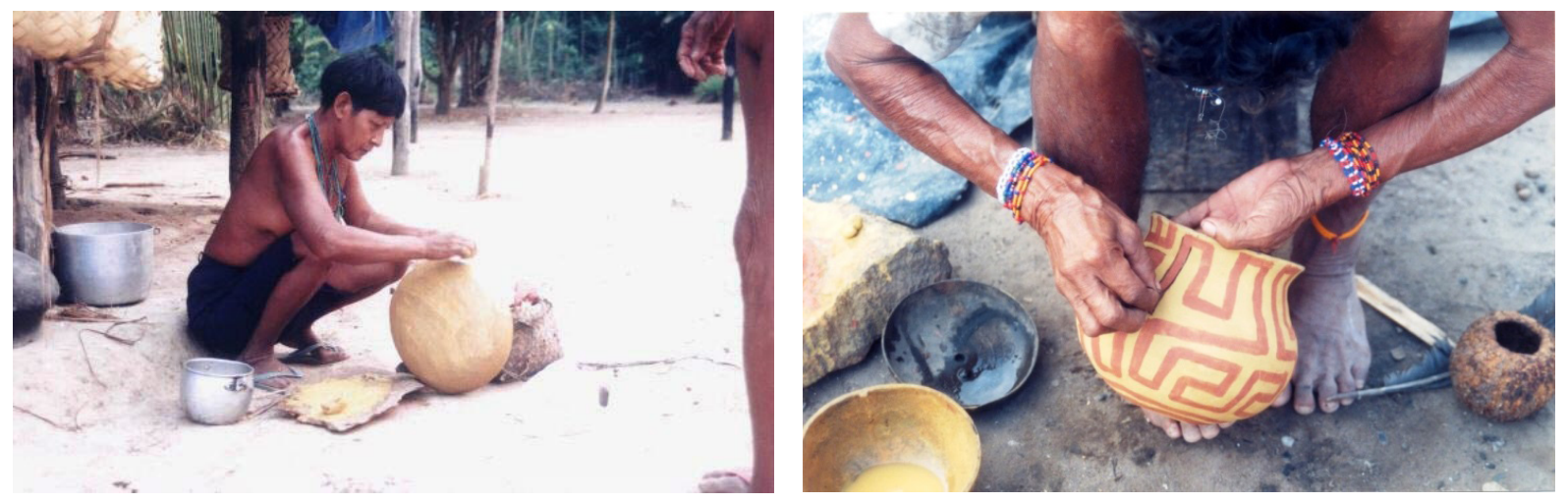

When the mineral pigments are dry, the women pass jatobá (jutaika) resin on their outside surface. First, they clean the outside part of the resinous agglomerate (jutaika akatuak= prepare the jutaika) and place a piece of resin in a wooden fork (ywyrawaka= cracked stick). They heat the vessel (amukup mapapira = heat pot) and pass the resin, which melts upon contact with the surface of the vessel, varnishing it (Figure 15). The finer the layer of resin, the better will be the surface finish and this requires skill from the potter. As they pass the resin, they smooth it with a spatula made with the stem of a babaçu palm (pina'wipe). This step is called akatuaka pina'wipe pywu (fit, make beautiful with the palm stalk). While they pass the resin they should avoid eating, drinking, urinating or defecating. They say that these actions can cause the resin to harden and not spread with the perfection desired for the surface of the vessel.

Fig. 15. Passing the resin (jutaika) on the vessel

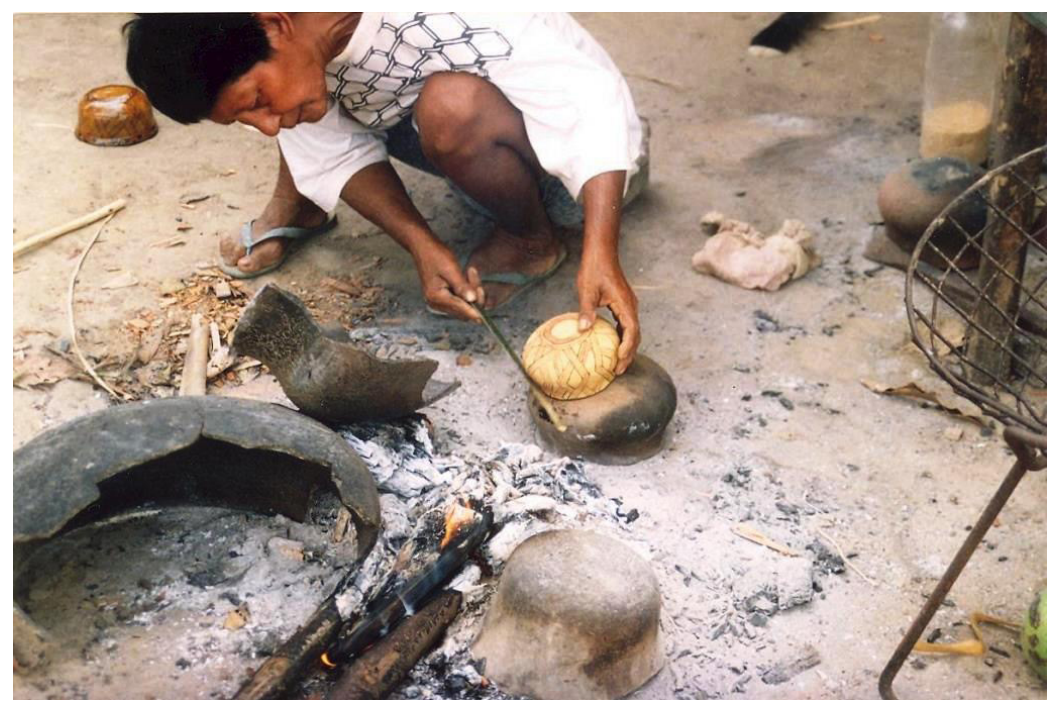


After this step is concluded they pass the titiva (resin from Inga sp) to "make the pot pretty inside and outside". They scrape the inside of the bark of the trunk of this tree (akay titiva = scrape titiva), removing the fiber impregnated with the resin, and as if it was a sponge, they rub it on the inside and outside surfaces of the vessel (mungavamu titiva mapapira = pass titiva on the vessel) - the resin is only applied to the outside to the vessels that go to the fire and are not painted (Figure 16 and 16a). As can be observed, this resin serves both to embellish, giving a shiny finish to the surfaces, and to seal the vessels - like a layer of Teflon. According to the Asurini, a vessel without the application of the titiva cannot be used for cooking or holding food. In practice, it is seen that without this layer of resin food sticks easily to the internal surface. Moreover, a vessel without titiva is considered to be poorly finished.

Fig. 16 and 16a. preparing the titiva to be applied on the internal surface of the kumé vessel
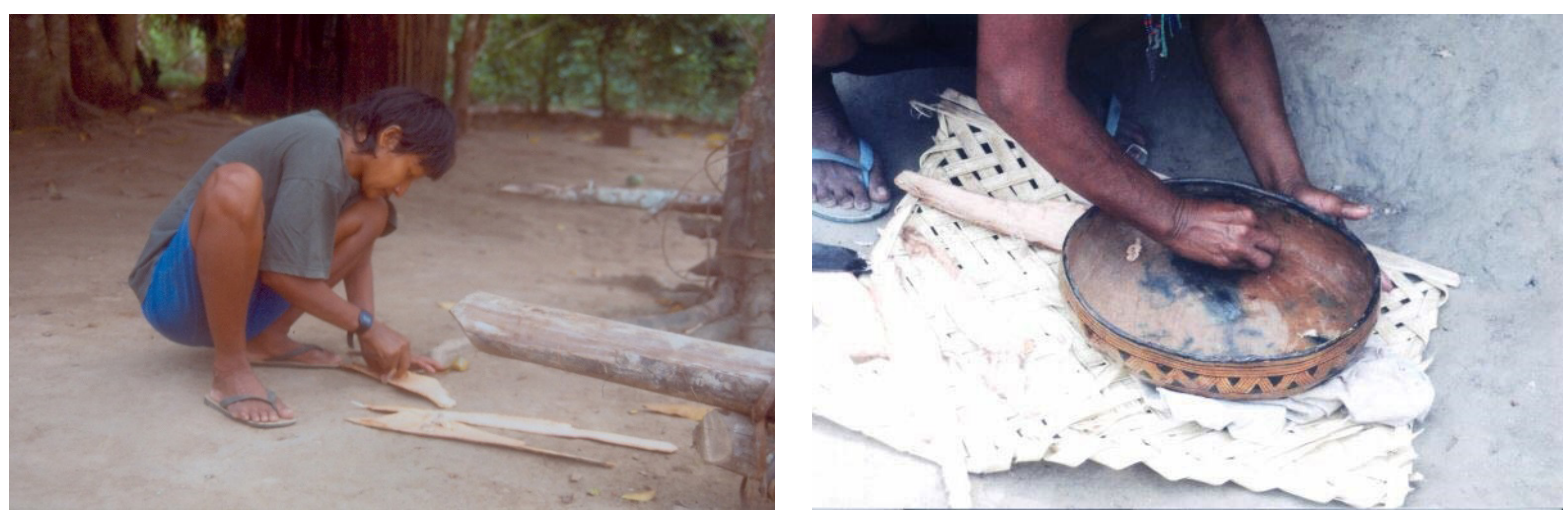

Painting reveals or highlights the different parts of the body of the vessel. This production step is the moment in which the creativity of the potters is exercised in full (Figure 17). The great variety of motifs allows the women to make different combinations of them. Thus, they paint the vessels either with a single motif, or with various motifs, producing a highly diversified and very particular repertoire of vessels. 
Fig. 17. Ceramic vessels with different combinations of motifs

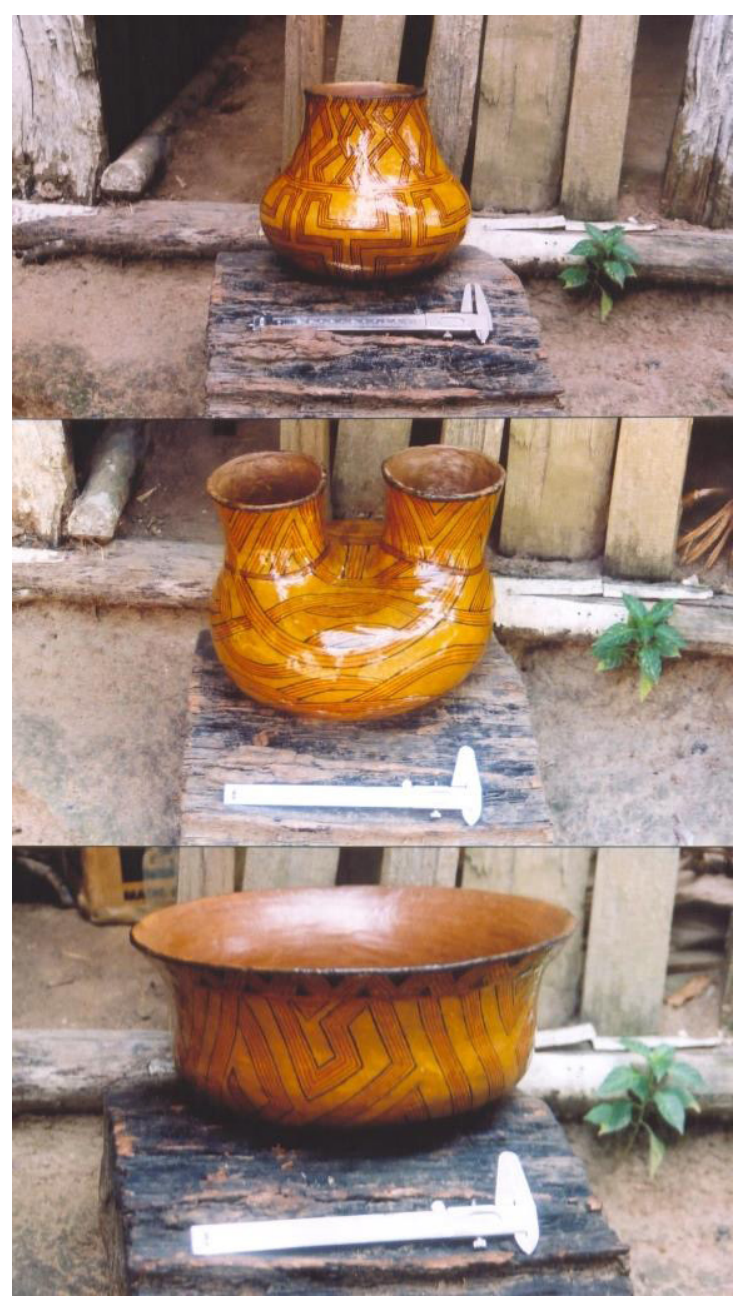

As Müller demonstrated (1990), the Asurini graphic art is constituted from a variety of combinations of geometric motifs (for ex. zig-zags, diamonds, straight lines, crossed lines, curved lines, diagonal lines, points, triangles), while most of these combinations include a structural pattern known as tayngava - characterized by a $90^{\circ}$ angle. Tayngava $a^{8}$ has been translated as "human image" and this is the name given to the anthropomorphic doll made with vegetable fibers used in the mburaai ritual and that is hung in the tukaia during the ritual performance. The mburaai is a propitiatory and therapeutic ritual in which, based on the agency of the shamans and the consumption of the porridges, the ynga (principle/vital energy) is shared among the beings (humans and non-humans) of the Asurini cosmos (Müller 1990, 1992). Müller (1990:232-251) emphasized that the use of the anthropomorphic doll (tayngava) in the mburaai ritual allows understanding that in the Asurini cosmovision, human image (tayngava) and the principle/vital energy (ynga) are interlinked and that both are constitutive of being. That is, there is a correlation of meanings and a similar semantic use of the words

\footnotetext{
8 The etymology of the word tayngava, in comparison with other languages of the Tupi-Guarani linguistic family, allows identifying the following elements: $\mathrm{t}=\mathrm{a}$ relational prefix that indicates generic human possession; $a y n g=$ from the transitive verb $a$ 'yng from the class " $i a$ " to immitate; $a v(a)=$ suffix nominalizing of circumstance + argumentative case. Thus, ayngava is understood as "resulting from an instrument for imitating, or a place for imitating, or imitation", given that this imitation can be functional, that is, in the sense of "being in the function of" or "that is in the place of" (personal communication Ana Suelly Arruda Câmara Cabral 2015).

9 The tukaia is a structure made of a plant material that serves as a hideout a hunter uses in the forest while watching the prey. In the mburaai ritual this structure serves as a "hideout" for the supernatural, and has different designs, according to the being that must be hidden (for ex. tivá, apikwara, arapuá, tajaú).
} 
tayngava (human image) and ynga (principle/ vital energy): ynga is the substance that constitutes the living beings (humans) /undivideds and that are different from those who do not have it, that is, who are añynga, beings (nonhumans, dead) who are absent/divided; as human image, tayngava refers to living beings (humans)/undivideds who possess ynga. In addition, according to the author, in graphic art, the tayngava pattern reveals the link between the different domains and beings of the cosmos - a single motif can be called tayngava and javosifafera (jaboti paw), tayngava and tembekwaropitá (the base of the lip ornament), tayngava and jagivaky (branch of the jagiva tree), tayngava and tayngava eté (true) - and relates to the ontological principle that the human is the image of the being.

According to Asurini cosmology, humanity obtained the patterns of the graphic arts after the encounter of the mythic ancestral Añyngavui with the supernatural Añyngakwasiat. Añyngavuí had secretly reproduced in the weavings the graphic designs found on the body of this supernatural being and had taught them to the ancestors who passed them on from generation to generation (Müller 1990:252-253). These motifs were reproduced on the pottery, woven items, gourds, corporal adornments and body painting.

As various studies have shown, in the Amerindian theories about materiality, objects can be simultaneously persons and the objectification of subjectivities, of social relations, or even of non-material intentionalities (Santos-Granero 2009) and "their very existence indicates the presence (real or potential) of the Other" (Barcelos Neto 2008: 29). In the case of the Asurini, the motifs painted on the ceramic vessels refer to the mythic being Añyngakwasiat, they reproduce his image/body and in this sense, the ceramic objects reaffirm the principles of Asurini sociality and are themselves as persons.

\section{Spatial context of the production of ceramic vessels}

Among the Asurini there is a prescription in the use of space in the village to keep more or less demarcated the places related to collective activities (for ex. ports, the ritual space, tavyva, the indigenous association, football fields, a school, flour mills, pharmacy, FUNAI structures) and those related to the activities of the domestic and residential groups (for ex. residential units, domestic structures, yards, garbage sites). This spatiality defines a taskscape (Ingold 1993) in which various activities combine and overlap and whose temporality is eminently social and resides in the web of inter-relations between the multiple rhythms of Asurini life. In this dynamic of social life, the activities of production, use, storage and disposal of objects and food - which are defined by the prerogatives of gender - are all realized in the places destined for domestic activities. These places tend to be multifunctional to the degree that various actions are realized in them, concomitantly or over time. In addition, these places are either abandoned, or transformed into other places and this takes place through the rhythms of Asurini life as well as the seasons of the year (for ex. the areas of activities are abandoned or redimensioned in the rainy season and in the dry season). Thus, the places have different dynamics and meanings during their uses (Silva 2000, 2008).

In relation to the production of ceramic vessels, the women normally conduct the activities of preparation of the raw materials in the yards between the residential units, or in the structures for cooking and storage. The preparation of the vessels, in turn, takes place both in the yards, and in the structures for cooking and storage, and in the residential units themselves. The activities of painting and applying the resins are conducted in yards, domestic structures, and depending on the light, inside residential units. The application of jatobá resin (jutaika) is usally conducted by taking advantage of a cooking fire, and preferably, in the first hours of morning when the temperature is more amenable. The firing of the vessels is an activity conducted in the yards, farther from residential units, in areas with little circulation of people, and nearly always in late afternoon. All of the raw-materials and tools needed to prepare the vessels are stored inside the residential units (for ex. pigments, resins, tools) and in the yards or domestic structures (for ex. clay, tools). 
All of the steps for producing the clay vessels are conducted in the same places as and concomitantly with the various other daily domestic activities; that is, there are no places specifically destined for the production of the ceramic vessels as there are in other pottery-making contexts. Thus, the spaces where pottery is made can also be used for the preparation, consumption and stocking of food, to do body paintings, and for manufacturing various other objects (for ex. baskets, stools, corporal ornaments, hunting tools, etc.). At the same time, ritual performances are also conducted in these spaces (for ex. mburaai). In this multifunctional dynamic of the places destined for domestic activities, the potters momentarily define specific spaces for pottery making. Nevertheless, they must always be attentive to the movement of people and especially of children who often destroy, in just seconds, a recently made vessel - a fact that is accepted naturally and becomes a pretext for them to begin again (Silva 2000).

\section{Producing clay vessels and (re)producing bodies}

For different Amazonic indigenous peoples, there is a correspondence between objects and bodies. Thus, objects can be like bodies or parts of bodies, and bodies can be like objects (for ex. Lagrou 2009; Hugh-Jones 2009). In this correlation (object-body $\leftrightarrow$ body-object) it is perceived that the concepts of fabrication, the definition of the constituent parts of objects and in the same way, their decorative cannons, follow principles similar to that of human bodies. In the Wayana ontology, for example, objects are manufactured with the same techniques as humans and are born, live and die like humans (van Velthem 2003).

The Asurini's clay vessels are also like bodies and this is evident in the way that they describe the constituent parts of their morphology: edge=eme (lip); diameter of the opening=juru (mouth); base=ekara (buttocks); internal bottom=aua; body = ga' $a$ (holder, belly). In addition, the sequence of operations realized during the productive process emphasizes this morphological division, given that a vessel is produced by parts, from the base to the lip, finally receiving the surface treatment (resin of ingá or titiva, painting, resin of jatobá or jutaika), given that the painting on the vessel highlights these divisions that refer to the body. The relationship between ceramics and body is also evident in the fact that the women share substances (saliva) with the ceramic vessels and simultaneously consume the raw material that they are made of (clay). They also exercise different types of care for their bodies from the time of gathering the clay until the passing of the resin of jatobá (jutaika), and together with the learning of the techniques of making ceramics they also learn the corporal techniques related with this knowledge (for ex. the seated or squatting position) ${ }^{10}$.

Finally, it is important to say that the clay vessels are the property of women, goods that they accumulate and exhibit with pleasure to others. Recalling Lévi-Strauss (1986:164) it can be said that an Asurini woman "metamorphizes in her products; from [being] physically exterior [to it] she becomes morally integrated to it". Thus, when she dies, her vessels go with her, because they are broken and thrown out, and according to the Asurini, this is done "so that no one will remember her, miss her". The Asurini clay vessels are bodies and simultaneously the objectification of the subjectivity of those women who produce and use them".

\section{The technology of ceramic production and the things of the whites}

Since their official contact in 1971, the ceramic technology of the Assurini has been observed and registered by different researchers (for ex. Müller 1990; Silva 2000, 2008, 2013). In these works, what was evident is that the steps of the operational sequence are the same, despite nearly 50 years of contact with the non-indigenous. However, this does not mean that there were no transformations in the technical choices. In this sense, by

10 The video "As mulheres das cócoras" [The Squatting Women] produced by Regina P. Müller and Graziela Rodrigues clearly shows what was described. HTTP://www.youtube.com/watch?v=SinFo62gNDE. 
incorporating the concept of technological tradition as a set of "shared dispositions that guide the technical choices" (Dietler e Herbich 1998:255) - emphasized at the beginning of the article - I do so because I understand that it allows me to consider the technologies as a dynamic corpus of knowledge; an idea that has been worked with by other authors in their reflections on the notion of technology (for ex. Chilton 1998; Dietler and Herbich 1998; Ingold 2000; Mura 2011).

In the twenty-three years in which I have been dedicated to the study of the ceramic technology of this people I have observed that some women invest in technical innovations in relation to trying to "imitate the things of the whites" (for ex. large jars for water, perfume flasks, fruit bowls, candle holders, ash trays) (Figure 18). These innovations were quickly abandoned, because they did not attain the aesthetic excellence sought by the ceramicists. Specifically relating to the clay vessels, some tried to produce vessels with lids, and also innovated in the painted patterns, in this case, investing in different combinations of colors (background/ design). The pots with lids were abandoned, but the experiments with the painting continue to be made, because they involve something that they appreciate and consider aesthetically gratifying. Over the years, there was a gradual increase in the production of miniatures of vessels that reproduce the types used as a didactic resource for teaching the girls, with this being a generalized choice among the women. All of these innovations and the preeminence of the miniatures were motivated by the desire for commercialization. It is important to say, that because of the sale of miniature vessels, the girls could enter the market of "craft sales".

Fig. 18 candle holder made for sale

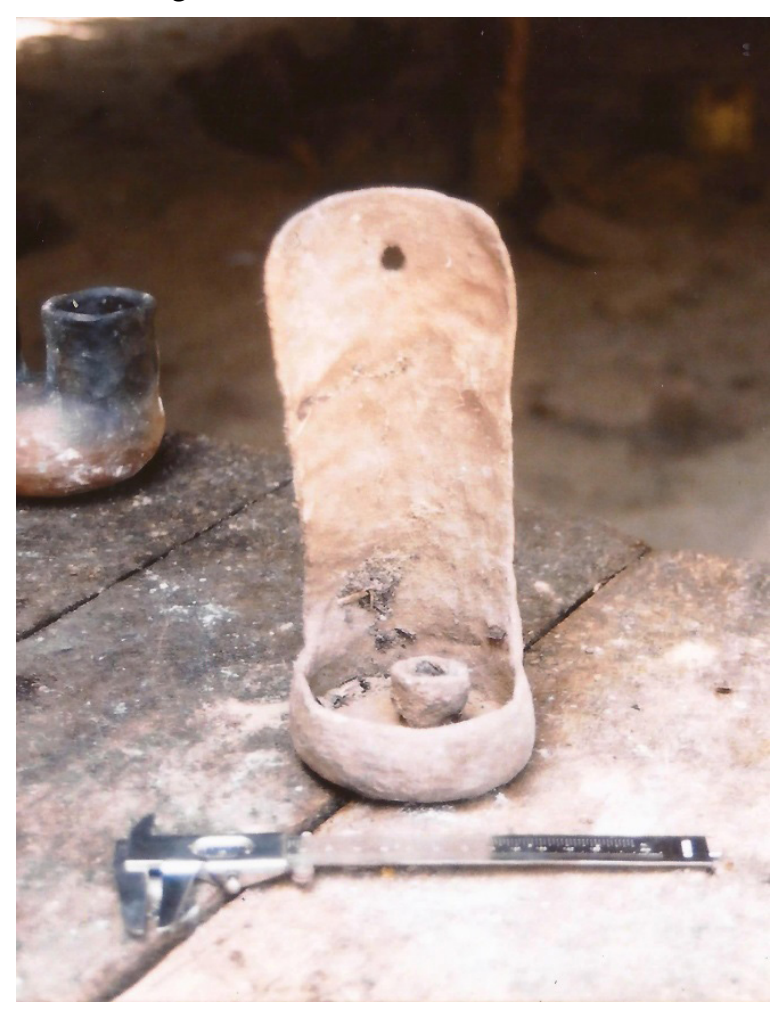

Nevertheless, in my view, what is interesting to highlight is the fact that ceramic vessels were increasingly being substituted by aluminum pots in daily use, given that the Asurini consider them to be as or more effective than the ceramic vessels for cooking. In this case, the women work to improve their "acquisition techniques" (Mura 2011:119), because the types of aluminum pots - in terms of morphology, size and thickness - are acquired according to their effectiveness for processing the different types of foods (cultivated or industrialized) to be consumed. These aluminum pots are usually very well cared for and cleaned, emphasizing once again the aesthetic concern of the Asurini women. 
In other studies I examined in depth and detail the transformations in the Asurini's technologies for production and use, contextualizing them in terms of their relations with the non-indigenous and the intensification in the purchase of industrialized goods and products. At the same, I sought to demonstrate how these transformations in techniques are articulated with social, political, economic and cosmological aspects (p.ex. Silva 2009a, 2009b, 2013). In this sense, I reaffirm that the technological transformations among the Asurini involve: "1) the creation of new objects and or the recreation of traditional objects from industrialized raw materials, objects and tools; 2) the diversification of supports, pigments and raw materials for the graphic art; 3) the substitution of traditional artifacts and tools for industrialized artifacts; 4) the acquisition of industrialized goods and raw materials and the learning of new technical procedures". These transformations should be understood through the principle of Asurini ontology that it is essential to encounter alterity to construct identity, with these new technical choices being "synonyms of cultural vitality and (re) creation" (Silva 2013:735, 741).

Fig. 19 domestic shelf with aluminum pots

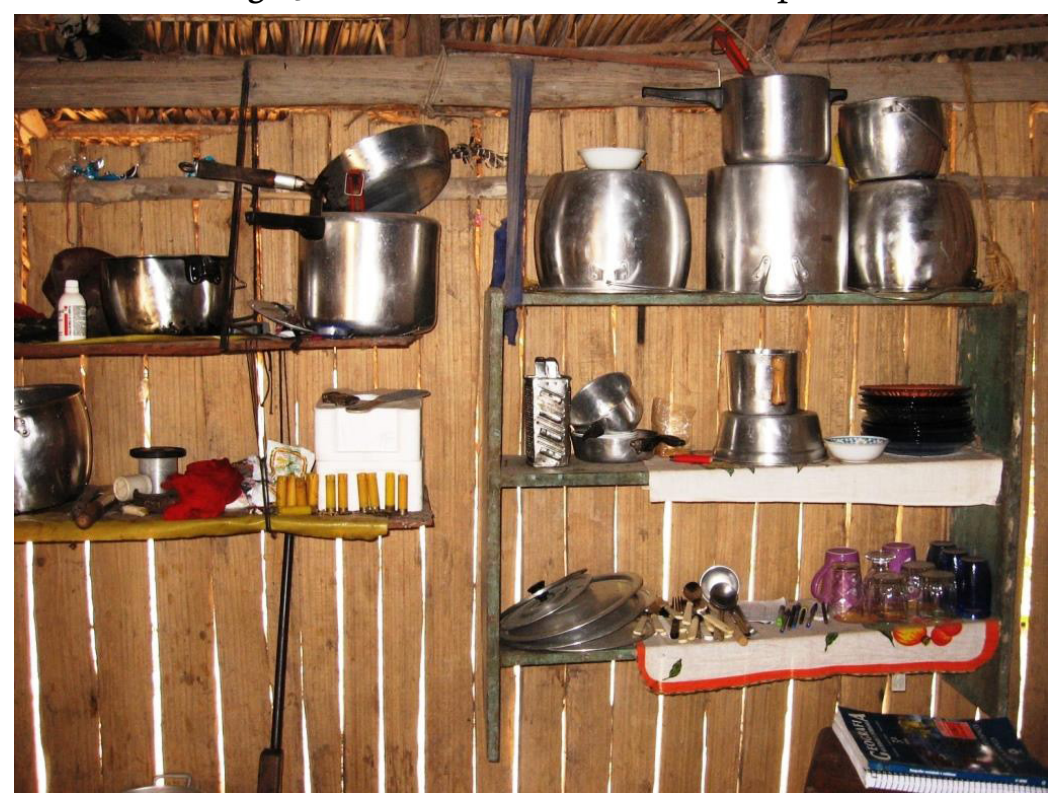

\section{Technologies and technical processes as (re)creation of the world}

Various authors have sought to emphasize that beyond their material and pragmatic aspects, technologies are social constructs that produce meanings (p.ex. Dietler and Herbich 1989; Gosselain 1999, 2000; Lemonnier 1992, 1993, 2012; Pfaffenberger 1992; Silva 2000), or even that technical processes are embedded in the web of social relations, while technical relations must necessarily be understood in this relational matrix "as an aspect of human sociality" (Ingold 2000:314).

Reflections were also realized to understand the techniques as being constituted by skills developed and acquired by people during their lives, whether through their involvement with each other in the realization of their activities, or through their own experiences with the materials, energies and or substances (tangible and intangible). Thus, they would be simultaneously acquired knowledge and the practice of knowledge (Ingold 2000). 
Therefore, for some authors, the processes of selection of materials and or substances, tools, and technical processes and the definition of the sequences of technical actions - the technical choices - result from a socially learned perception and at the same time, during their lives subjects experience the way that things should or should not be done and or used (for ex. Gosselain 2000, 2018; Herbich and Dietler, 2008)"1.

These perceptions and reflections about technologies and techniques reveal that technical processes are always invested by meanings, and that technical actions, like other social practices, are engendered through a "habitus" and, therefore, also transform over time. In my view, this is why it is important to conduct ethnographic descriptions of technical processes, as I sought to do in this text. This does not involve conducting a mere inventory of technical actions, tools, materials and sequence of production steps, but to show that the operational sequence is a "web of social, ecological and historic relations" (Gosselain 2018:1), which expresses a specific mode of engagement of certain subjects in the technical activities. It involve seeking to reveal "the processual and relational histories" (Ingold 2011b) that are at the base of these social practices. In recent years, various studies about the animist and transformational character of the Amazon Amerinidan cosmologies sought to highlight the importance of objects in the sphere of relations between humans and non-humans (for ex. Santos-Granero 2009). During this period, some authors have also reflected on technical processes, showing that for different indigenous peoples they have an ontological relevance, and are grasped as transformative and symbolic action for the (re)creation of the world (for ex. Barcelos Neto 2005/2006, 2008, 2009; Belaunde 2017; Hugh Jones 2009; Silva 2000, 2008, 2011; van Velthem 2003, 2009).

In the case of the Asurini, their ceramic production technology is characterized for bringing to the sensitive universe, in a concomitant manner, functional, aesthetic, social and ontological precepts of this Amazon people. During all the phases of the chaine opératoire, the notions of utility and beauty coexist with the themes of Asurini sociality and cosmology.

Although this article did not analyze the structural aspects of the myths, or conduct an exegesis of all their ethnographic significance - a task that would involve the preparation of other articles - it is possible to see that there is a mythic repertoire in which ceramic objects and their productive processes appear to reaffirm different ontological principles of this Amazon people. The Asurini acquire the techniques, materials and energies needed for the production of ceramic objects based on their relations with animals (bees, rabbits, beetles, vultures) - which in mythic times were all human - and with Maíra, the demiurge who through a creative act, made the clay, just like the mythic ancestors Añyngavuí and Anumaí, being that the first copied the corporal designs of Añyngakwasiat, and the second, sister of the primordial shamans, left the shards of her vessels spread on the ground. For the Asurini, only humans can make ceramics, because where the non-human "others" live there is no clay, and for this reason their vessels are all used and very worn.

Thus, by making ceramic objects, the Asurini women reiterate relations between different types of persons (humans and non-humans), revise the ontological principles of grasping the materials and of acquisition of technical knowledge, reaffirm their social relations and roles, reveal the significant aspects of domestic space and interlink different temporalities, living the dynamics of their way of life at the encounter with alterity.

I understand that this ceramic technology corresponds to what Alfred Gell (1992:43-44) defined as a "technology of enchantment", based on "enchantment of the technology". The enchantment, in this case, is in the capacity that the ceramic objects and technical processes have to act as indexes and agents of the creative and aesthetic virtuosity of the Asurini women, as well as of the relations between persons (human and non-human) and different worlds (of humans, supernatural beings and materials).

11 Considering that this article is not a theoretical reflection on the field of anthropology of techniques and technology I will not focus on explaining the different meaning given to the terms technology, technique, technological sets and technological systems by different authors. I intend, however, to highlight that I am dialoging mainly with authors who despite their divergences in certain contents, have sought to reveal that technical processes are an integral part of social practices. 
Their agentivity, in this case, stems from an intersubjective relation with the human agent, considering that in Asurini thinking, vessels and technical processes are the embodiment of persons and also the objectification of relations between persons.

The ceramic production technology of the Asurini of the Xingu is an expression of a transformational and symbolic process. Different things, bodies and people are transformed, and meanings are triggered and produced that transcend the act itself of producing ceramic vessels. This technology (re)creates the world of the Asurini of the Xingu.

Received: April 14, 2019

Approved: August 8, 2019

Translated by: Jeff Hoff

\section{References}

ARNOLD, Dean. 2000. "Does the standardization of ceramic pastes really mean specialization"? Journal of Archaeological Method and Theory, 7(4): 333-375.

ARTHUR, John. 2006. Living with pottery: ethnoarchaeology among Gamo of Southwest Ethiopia. Salt Lake City: University of Utah Press.

BANKS, Marcus; MORPHY, Howard. 1997. “Introduction: rethinking visual anthropology”. In: M. Banks, H. Morphy (eds.), Rethinking visual anthropology. New Haven/London: Yale University Press. pp. 36-52.

BARCELOS NETO, Aristóteles. 2005/2006. "A cerámica Wauja: etnoclassificação, matérias-primas e processos técnicos". Revista do Museu de Arqueologia e Etnologia, 15/16: 357-370. . 2008. Apapaatai. Rituais de Máscara no Alto Xingu. São Paulo: EDUSP/FAPESP. . 2009. "The (de)animalization of objects: food offerings and subjectivization of masks and flutes among the Wauja of Souther Amazonia”. In: F. Santos-Granero (ed.), The occult life of things. Native Amazonian theories of materiality and personhood.Tucson: University of Arizona Press. pp. 128-151.

BELAUNDE, Luiza E. 2006. "A força dos pensamentos, o fedor do sangue: hematologia e gênero na Amazônia”. Revista de Antropologia, 49(1): 205-243.

. 2017. "Viver bem e a cerâmica: técnicas artefatuais e sociais na Amazônia". RAU. Revista e Antropologia da UFSCAR, 9(2): 185-200.

CARR, Christopher. 1995a. "Building a unified middle-range theory of artifact design: historical perspectives and tactics". In: C. Carr; J.E. Neitzel (eds.), Style, Society and Person.(Archaeological and Ethnological Perspectives). New York/London: Plenum Press. pp. 151-170.

. 1995b. "A unified middle-range theory of artifact design". In: C. Carr; J.E. Neitzel (eds.), Style, Society and Person.(Archaeological and Ethnological Perspectives). New York/London: Plenum Press. pp. 171-258.

CHILTON, Elizabeth. 1998. "The cultural origins of technical choice: unraveling algonquian and iroquian ceramic traditions in the northeast”. In: M. Stark (ed.), The archaeology of social boundaries. Washington/ London: Smithsonian Institution Press. pp. 132-160.

DIETLER, Michael; HERBICH, Ingrid. 1989. "Tich matek: the technology of Luo pottery production and the definition of ceramic style". World Archaeology, 21(1): 148-154. 
. 1998. "Habitus, techniques, style: an integrated approach to the social understanding of material culture and boundaries". In: M. Stark (ed.), The archaeology of social boundaries. Washington D.C.:

Smithsonian Institution Press. pp. 232-263.

EDWARDS, Elizabeth. 2001. Raw histories. Photographs, anthropology and museums. Oxford: Berg.

FAUSTO, Carlos. 2008. "Donos demais: maestria e domínio na Amazônia”. Mana, 14(2): 329-366.

GELL, Alfred. 1992. "The technology of enchantment and the enchantment of technology". In: J. Coote; A.

Shelton (eds.), Anthropology, art and aesthetics. Oxford: Claredon Press. pp. 40-63

GOSSELAIN, Olivier. 1992. “Technology and style: potters and pottery among Bafia of Camerron”. Man, 27(3): $559-585$.

. 1999. "In pots we trust: the processing of clay and symbols in sub-Saharan Africa". Journal of Material

Culture, 4(2): 205-230.

. 2000. "Materializing identities: an African perspective". Journal of Archaeological Method and Theory,

$7(3): 187-217$.

. 2018. "Pottery chaînes opératoires as historical documents." In: T. Spear (ed.), Oxford Research

Encyclopedia of African History. Oxford: Oxford University Press. pp.

HAOUR, Anne; MANNING, Katie; ARAZI, Noemi; GOSSELAIN, Olivier; GUÈYE, Ndèye; SMITH, Alexandre

L.; MacDONALD, Kevin; MAYOR, Anne; McINTOSH, Susan e VERNET, R. 2010. African pottery roulettes past and present: techniques, identification and distribution. Oxford: Oxbow Books.

HEGMON, Michele. 1992. "Archaeological Research on Style". Annual Review Anthropological, 21: 517-536.

. 1998. "Technology, style, and social practices: archaeological approaches". In: M. Stark (ed.), The

archaeology of social boundaries. Washington: Smithsonian Institution Press. pp. 264-28o.

HERBICH, Ingrid; DIETLER, Michael. 2008. "The long arm of the mother-in-law: learning, postmarital resocialization of women, and material culture style”. In: M. Stark, B. Bowser e L. Horne (eds.), Cultural transmission and material culture. Breaking down boundaries. Tucson: The University of Arizona Press. pp. 223-244.

HUGH-JONES, Stephen. 2009. "The fabricated body: objects and ancestors in Northwest Amazonia”. In:

F. Santos-Granero (ed.), The occult life of things. Native Amazonian theories of materiality and personhood.

Tucson: University of Arizona Press. pp. 33-59.

INGOLD, Tim. 1993. "The temporality of the landscape". World Archaeology, 25: 152-174.

. 200o. The perception of environment: essays on livelihood, dwelling and skill. London: Routledge.

. 2011a. "Materials against materiality". In: Being alive. Essays on movement, knowledge and description.

London: Routledge. pp. 19-32.

. 2011b. "Toward an ecology of materials". Annual Reviews of Anthropology, 41: 427-442.

LAGROU, Elsje. 2009. "The crystallized memory of artifacts a reflection on agency and alterity in Cahinahua image-making”. In: F. Santos-Granero (ed.), The occult life of things. Native Amazonian theories of materiality and personhood.Tucson: University of Arizona Press. pp. 192-213.

LA SALVIA; BROCHADO, José J. P. 1989. Cerâmica Guarani. Porto Alegre: Posenato Arte e Cultura.

LEMONNIER, Pierre. 1992. Elements for an anthropology of technology. Michigan: Museum of Anthropological Research/University of Michigan.

. (ed). 1993. Technological choices. Transformation in material cultures since the Neolithic. London:

Routledge.

. 2012. Mundane Objects. Materiality and non-verbal communication. Walnut Creek: Left Coast Press.

LEEUW, Sander van der. 1993. "Giving the potter a choice”. In: P. Lemonnier (ed.), Technological choices.

Transformation in material cultures since the Neolithic. London: Routledge. pp. 238-288.

LÉVI-STRAUSS, Claude. 1986. La alfarera celosa. Barcelona: Paidos Studio. 
LONDOÑO SULKIN, Carlos D. 2012. People of substance. An ethnography of morality in the Colombian Amazon. Toronto: University of Toronto Press.

MACEACHERN, 1998. "Scale, style, and cultural variation: technological traditions in the northern Mandara mountains”. In: M. Stark (ed.), The archaeology of social boundaries. Washington/London: Smithsonian Institution Press. pp. 107-131.

MILLER, Daniel. 1985. Artefacts as categories. A study of ceramic variability in Central India. Cambridge: Cambridge University Press.

MÜLLER, Regina P. 199o. Os Asurini do Xingu (história e arte). Campinas: Editora da Unicamp. . 1992. "Tayngava, a noção de representação na arte gráfica”. In: L. B. Vidal (org.), Grafismo indígena. São Paulo: Studio Nobel/Edusp/Fapesp. 231-248. . 2002. "As crianças no processo de recuperação demográfica dos Asurini do Xingu". In: A. Lopes da Silva; A. V. L. da Silva Macedo e A. Nunes (orgs.), Crianças indígenas. Ensaios antropológicos. São Paulo: MARI/FAPESP. pp. 188-209.

MUNITA, Casemiro; SILVA, Fabíola A.; OLIVEIRA, Paulo. 2005. "Archaeometric study of clay deposits from indigenous land of the Asurini do Xingu". Instrumentation Science \& Technology, 33(2): 161-173.

MUNN, Nancy. 1977. "The spatiotemporal transformations of Gawa canoes". Journal de la Soc. des Océanistes, 33: 40-51.

MURA, Fábio. 2011. "De sujeitos e objetos: um ensaio crítico de antropologia das técnicas e da tecnologia". Horizontes Antropológicos, 17(36): 95-125.

PFAFFENBERGER, Brian. 1992. "Social anthropology of technology”. Annual Review of Anthropology, 21: 491516.

RIBEIRO, Berta. 1982. "A oleira e a tecelã”. Revista de Antropologia, 26: 25-61.

RIBEIRO, José da S. 2005. "Antropologia visual, práticas antigas e novas perspectivas de investigação". Revista de Antropologia, 48(2): 613-647.

RICE, Prudence. 1987. Pottery analysis. A sourcebook. Chicago: The University of Chicago Press.

SAMAIN, Etienne. 2006. Questões heurísticas em torno do uso das imagens nas ciências sociais. In: B. Feldman-Bianco and M. L. Leite (orgs). Desafios da imagem. Fotografia, iconografia e vídeo nas ciências sociais. São Paulo: Papirus Editora. pp. 51-62.

SANTOS-GRANERO, Fernando. 2009. The occult life of things. Native Amazonian theories of materiality and personhood. Tucson: University of Arizona Press.

SEEGER, Anthony; MATTA, Roberto da; VIVEIROS DE CASTRO, Eduardo. 1987. "A construção da pessoa nas sociedades indígenas brasileiras". Boletim do Museu Nacional, 32: 2-19.

SILVA, Fabíola A. 2000. As tecnologias e seus significados. Um estudo da cerâmica dos Asurini do Xingu e da cestaria dos Kayapó-Xikrin a partir de uma perspectiva etnoarqueológica. Tese de Doutorado, Departamento de Antropologia, Universidade de São Paulo - São Paulo.

. 2008. "Ceramic technology of the Asurini do Xingu, Brazil: An ethnoarchaeological study of artifact variability". Journal of Archaeological Method and Theory, 15: 217-265. . 2009a. "A variabilidade dos trançados dos Asurini do Xingu: uma reflexão etnoarqueológica sobre função, estilo e frequência dos artefatos". Revista de Arqueologia, 22: 17-34. . 2009b. "A organização da produção cerâmica dos Asurini do Xingu: uma reflexão etnoarqueológica sobre variabilidade e padronização artefatual". Arqueología Suramericana, 5: 121-137. . 2010. "A aprendizagem da tecnologia cerâmica entre os Asurini do Xingu". In: A. Prous e T. A. Lima (orgs.), Os ceramistas Tupiguarani: eixos temáticos. Belo Horizonte: Superintendência do IPHAN de Minas Gerais. pp. 7-26. 
. 2011. "A tecnologia da cestaria entre os Xikrin-Kayapó”. In: F. Silva e C. Gordon (orgs.), Xikrin: uma coleção etnográfica. São Paulo: Edusp. pp.173-206.

. 2013. "Tecnologias em transformação: inovação e (re)produção dos objetos entre os Asurini do

Xingu". Boletim do Museu Paraense Emilio Goeldi, 8(3): 729-744.

.; PELLEGRINI, A. C. 2019. "Imagens dos Asurini do Xingu. Reflexões sobre um acervo fotográfico".

Revista Habitus, 17(1):163-184.

.; APPOLONI, Carlos .R.; QUIÑONES, Fernando R.E.; SANTOS, Ademilson O.; SILVA, Luzeli M.da;

BARBIERI, Paulo.; NASCIMENTO FILHO, Virgilio F. 2004. "A arqueometria e a análise de artefatos

cerâmicos: um estudo de fragmentos cerâmicos etnográficos e arqueológicos por fluorescência de raios X (EDXRF) e Transmissão Gama”. Revista de Arqueologia, 17: 41-61.

VAN VELTHEM, Lúcia H. 2003. O belo é a fera. A estética da produção e da reprodução entre os Wayana. Lisboa: Assírio e Alvim.

. 2009. "Mulheres de cera, argila e arumã: princípios criativos e fabricação material entre os Wayana".

Mana, 15(1): 213-236.

WALKER, Harry. 2009. "Baby hammocks and stone bowls: Urarina technologies of companionship and subjection". In: F. Santos-Granero (ed.), The occult life of things. Native Amazonian theories of materiality and personhood.Tucson: University of Arizona Press. pp. 81-102.

WIESSNER, Polly. 1983. "Style and social information in Kalahari San projectile points". American Antiquity, 48(2): 253-276.

\section{Acknowledgements}

I am immensely grateful to the Asurini women for their courtesy and patience during my learning about their ceramic technology. I would like to thank the Fundação de Amparo à Pesquisa de São Paulo (FAPESP) for the financial assistance provided during my research with the Asurini do Xingu and the Conselho Nacional para o Desenvolvimento Científico e Tecnológico (CNPq) for the productivity grant. I am grateful to Lorena L.W. Gomes Garcia for preparing the chart with the morphology of the ceramic vessels and to the editors Fabio Mura and Carlos Sautchuk for the opportunity to participate in this dossier.

\section{Fabíola Andréa Silva}

Museum of Archaeology and Ethnology

University of São Paulo

https://orcid.org/0000-0001-5995-4704

Author's e-mail: faandrea@usp.br 